\title{
Embodiment and Ambivalence: Emotion in South Asian Muharram Drumming
}

\section{Citation}

Wolf, Richard K. 2000. Embodiment and ambivalence: Emotion in South Asian Muharram drumming. Yearbook for Traditional Music 32: 81-116.

\section{Published Version}

doi: $10.2307 / 3185244$

\section{Permanent link}

http://nrs.harvard.edu/urn-3:HUL.InstRepos:4137949

\section{Terms of Use}

This article was downloaded from Harvard University's DASH repository, and is made available under the terms and conditions applicable to Other Posted Material, as set forth at http:// nrs.harvard.edu/urn-3:HUL.InstRepos:dash.current.terms-of-use\#LAA

\section{Share Your Story}

The Harvard community has made this article openly available.

Please share how this access benefits you. Submit a story.

Accessibility 


\title{
EMBODIMENT AND AMBIVALENCE: EMOTION IN SOUTH ASIAN MUHARRAM DRUMMING ${ }^{1}$
}

by Richard K. Wolf

\begin{abstract}
Wolf: How long will the drums play before the procession starts? Bashir Husein Mazhar (Multan, Pakistan): The drums are playing for this, to show the sorrowness... one drum will be beating for happiness and also the drums beating are for, to show the sorrowness ... and it is in our Arab culture to show the drums in our sorrowness.
\end{abstract}

In this article, I pursue a line of inquiry that contends with music and the emotions: how and in what circumstances does music represent or generate the often subtle range of emotions characteristic of mourning rituals for participants in those rituals? My preliminary insights draw on two-and-a-half years' fieldwork with ritual drummers, during which I lived in Lahore, Pakistan and Lucknow, India and traveled extensively in the subcontinent. ${ }^{2}$ Using the practice of drumming during the Sh'̄ī observance of mourning, Muharram, as a case study, I wish to illustrate how localized interpretations of drumming contexts tend to bleed into interpretations of drumming content, and suggest that the study of musical culture may provide a unique perspective on the emotional multivalence or ambivalence that diverse participants experience in Muharram more generally. In Section I, I begin with a brief theoretical review of two themes, "embodiment" and the "complexity of emotions." In Section II, I proceed to provide further background on Shi' 'ism, Muharram, and the status of music. The body of the paper examines three ways in which drumming signifies in a general sense: Enduring contextual associations (Section III); assignments of meaning (Section IV); and aesthetics of drumming (Section V). Before laying the theoretical backbone of this exploration, however, it will be necessary to know a bit about Muharram as an occasion and why a person might feel ambivalent about it in the first place.

Muharram commemorates the pitched battle (680 C.E.) of Karbala, in present day Iraq, which many now understand to have been a struggle over the political and spiritual leadership of Islam. As always, the present colors the interpretation of the past, and the "presents" I was exposed to were those of south Asian Shī ${ }^{\prime} \bar{i}$ Muslims. To simplify, Husain, grandson of the Prophet, was slain by the henchmen of the Ummayad ruler Yazid, whose (reputedly) lavish and imperialist style of governance was, in the opinion of Husain and his followers, contrary to the egalitarian spirit of Islam. Shī 'ahs dwell on the tragic martyrdom of a number

\footnotetext{
' Versions of this paper were delivered at the 1999 Conference on South Asia at the University of Wisconsin, Madison, and at the workshop, "Text, Context and the Constitution of Difference in Middle Eastern Studies" at the Ben-Gurion University in the Negev (June 2000). I would like to thank participants in these events for their critical suggestions. I also wish to thank Amy Bard, James Kippen, Frank Korom, C. M. Naim, and Regula Qureshi for their helpful comments.

${ }^{2}$ Important additional sites included Karachi, Hyderabad, and rural Sindh; Multan and rural Pakistani Panjab, villages near Lucknow, Almora town, villages in Basti district of Uttar Pradesh; Delhi; Hyderabad and surrounding rural areas in Andhra Pradesh; villages in Dharmapuri district, and Madras, Tamilnadu; Calcutta city; Bombay; and Udaipur, Rajasthan. I wish to thank the following persons for field and translation assistance: Qamar Jalil (Panjabi, Urdu), Amy Bard (Urdu), M. Laxmaiah (Telugu), Nagaraj (Telugu), Chotu Singh (Mewari), Saglain Naqvi (Urdu).
} 
of characters in their redactions of the story, including Ali Asghar and Ali Akbar, Husain' s sons; Abbas, Husain' s half brother; Hur, who defected from the Ummayad army; and Qasim, son of Husain' s brother Hasan. Many believe that the Imāms (spiritual leaders and successors to Muhammad) and martyrs of Karbala are present during Muharram and, like Sufi saints, intervene on behalf of the devout. Part of the ambivalence over Muharram stems from the fact that Husain' s martyrdom is considered a moral victory. Thus, for Shī I Muslims, both mourning and celebration are deeply embedded in Muharram's emotional fabric.

Muharram is not, however, exclusively a Shī'i phenomenon in south Asia. Muharram has existed for hundreds of years as a complex public and private congeries of observances, whose meanings have varied for peoples of different backgrounds and belief systems. This multiple participation accounts for additional affective entanglements. Already in the early $19^{\text {th }}$ century, according to the historian Jim Masselos, there was in Bombay "a degree of ambivalence in the character of the event," in that "what was a time for mourning also looked like a festival or carnival" (Masselos 1982, 50); in Lahore mourning, celebration, and conflict were observed as part of the proceedings as early as about 1635 (Cole 1988, 25; Rizvi 1980, 191). ${ }^{3}$ However, now, Shī 'ahs living in urban south Asia tend to view such a festival-like atmosphere, created in part by the presence of drumming, as completely external to the "real," i.e. Shī'i, Muharram. ${ }^{4}$ This examination locates drumming in the broader phenomenon of Muharram in the subcontinent, not merely in the "Muharram" constructed by religious authorities of the $1990 \mathrm{~s},{ }^{5}$ and assesses historical changes in the musical culture of drumming.

\section{Theoretical Background}

My arguments about the intricacies of emotionality hinge on the capacity of drumming to be interpretively ambiguous. Unlike singing, reciting, and melodic rendering of songs, drumming derives little semantic import from verbal texts. No commonplace system links rhythms, like rāgās, with aesthetic and emotional essences (rasas and bhāvas). Since the field of drumming is left rather open to interpretation, it serves as an ideal window into the production of meanings in

\footnotetext{
${ }^{3}$ Rizvi quotes the Bahr Ul-Asrār travelogue of the central Asian traveler Mahmud b. Amir Wali. The edition of this work I consulted provided the date 23 September 1625 for Wali's visit to Lahore on the first of Muharram (Islam 1980, 26). The account begins on page six of the Persian section.

${ }^{4}$ This may well be connected with religio-political developments in Iran, where "the state . . . mandates a sad demeanor and expressions of grief as a sign of religious and political commitment" (Good and Good 1988, 45). See Pinault (1999) for further examples of the influence of the Iranian state on Indian practice, and some of its limitations. See also Malarney, who shows how in Vietnam, state functionalism can "engender a significant transformation of meaning, value, and ritual structure" in funerary rituals, but "can never control . . . [its full] range of meanings and values" $(1996,556)$.

${ }^{5}$ See Masselos who shows that "in the Bombay Mohurrum, the very concept of what constituted the major - the great - Islamic tradition varied over time. What might nowadays be considered the determinants of such a tradition, that of the Prophet, the Book, and external precedent, only came to be important for Mohurrum quite late in the span [of the $19^{\text {th }}$ and $20^{\text {th }}$ centuries]" (1982, 62).
} 
ritual. It becomes useful to explore how the formal and aesthetic qualities of drumming articulate with the emotional contours of Muharram.

It is surprising that more attention has not been paid to ritual aspects of drumming in the subcontinent: many ritual musical traditions, extending from the southern tip of India to the borders of Nepal and Bangladesh, and in Pakistan to the borders of Iran and China, are defined primarily by rhythmic pattern and only secondarily by melody. ${ }^{6}$ In considering Muharram drumming in south Asia as but one facet of a larger south Asian set of rhythmic ritual practices, I am in effect redirecting attention to the "homeland" lines of inquiry suggested by preliminary studies of Muharram drumming in the Indian diaspora, Trinidad, Sumatra and Bengkulu (Korom 1994a; Kartomi 1986; Feener 1995; 1999).

Emerging discussions of culture and the emotions in the humanities and social sciences - $\theta$ ver the past fifteen years especially - provide critical tools to probe the meanings of Muharram drumming. Implicit in my approach is that the study of musical culture may contribute to the ongoing problematizations of "emotion" in the fields of anthropology, cultural studies and psychology. Here the scope is limited to two themes, which I will weave throughout my discussion: 1) embodiment; and 2) emotional complexity: ambivalence-multivalence. I shall briefly trace the background of these themes and their relevance to the following discussion.

\section{Embodiment}

Recent critiques in cultural anthropology have attacked stereotypically "Western" dichotomizations of mind and body, implied in such (gendered) contrast sets as "rationalism" and "emotion," and "thinking" and "feeling" (Lutz 1988; Myers 1988). Some scholars have shifted focus to how emotions are embodied (Leavitt, 1996) - without reducing local understandings to mere metaphor (Strathern 1993). ${ }^{7}$ Beyond suggesting that these distinctions between noetic and somatic knowledge are themselves culturally, socially and historically dependent, analyses have questioned the extent to which categories of feeling once thought to be universal can truly be understood cross culturally: there is a growing realization that although one may translate words such as "anger" (Lutz 1988) or "sadness" (Grima 1993) from one language to another, the implications, valuations, and social use of these terms and the "emotions" to which they refer are not givens, but rather constitute focal points for investigation.

These issues are relevant for understanding Muharram performances in south Asia because emotionality - physically manifest in weeping, shouting,

\footnotetext{
${ }^{6}$ My findings, though limited by the geographical scope of my fieldwork, are supported by Flora's observations: the "naubat genre and style," can be identified by "rhythmic patterns on the naqärah. . the śahnāi has a secondary role" $(1995,60)$. In Nepal, similarly, items of occasional repertoire for the pancāl bājā are identified either by melody or by rhythmic pattern, cāl (Tingey 1994, 120). The context-defining properties of percussion and rhythmic patterns in ritual music of south Asia deserve further attention.

${ }^{7}$ In keeping with the principles of these critiques, as I view them, I will not adopt the distinctions some scholars have drawn between the terms emotion, affect, sentiment, and feeling, for these distinctions generally depend on assumptions about differences between inner states, described states, symbolic expression and culture that are not themselves universal (Grima 1993, 7). Rather, I will use these terms loosely, depending on everyday understandings of American English usage, and attempt to tease out the ethnographic particularities of my subject matter through description - limited though it may be.
} 


\section{4/2000 YEARBOOK FOR TRADITIONAL MUSIC}

sighing, and bodily mortification - is a central component of Shī'i piety as it is lived. How and where is emotionality generated and who defines it? To what extent do participants regard specific emotions as inherent in verbal performance texts? How are they constituted in more abstract - to some, more viscerally "felt" - forms such as melody and rhythm? How do these two kinds of emotional meanings interface with what (several kinds of) texts communicate about "music"? These three ways in which performance forms may be affectively construed are distinct but constantly interacting. I wish to emphasize the theme of "embodiment" in this discussion because all three types of meaning production converge in, on, and through the body. The most obvious example of such embodiment is the practice of beating the chest (mätam), a "summarizing symbol" of (Ortner 1979), among other things, the redemptive role of suffering in Shī'i religious philosophy. The meanings of mâtam are generated through the three forms I mentioned: it is performed in conjunction with poetic recitation (part of its meaning is related to what the text conveys); it is aestheticized virtually to the point of becoming an art (part of its meaning derives from aesthetic qualities); and it is discussed in religious and critical texts (its meaning is debated explicitly in verbal form outside of the performance context). Drumming, like mätam, according to some participants, embodies the rhythmic character of lament poetry via patterned time it translates verbal performance into a type of movement. The dynamics of embodiment are brought to the fore as we examine the possible relationships between drumming and breast beating in both rhythmic and moral terms.

\section{Emotional Complexity}

Studies of emotion in culture have paid increasing attention to the second theme of this paper, emotional complexity: e.g. the affective and motivational differences of participants in funerary rituals (Metcalf and Huntington 1991; Venbrux, 1993; Cannon, 1989); the relationships of different emotions produced in a dialectic interpersonal context (Lutz 1988; Myers 1988); or the ambivalence of emotions "linked to a person' s sense of value" (Kupperman 1997, 375). In the literature on funerals, for instance, anthropologists have emphasized not only the elements of sadness occasioned by a death, but the cultural phenomenon of the funeral, where elements of competitiveness, ostentation, and celebration depend upon both the social structure of the living and ethnotheories about what happens to the dead. In a similar vein, we may understand the affective complexity of Muharram partially as a function of the social organization of the event (participation of Hindus and Sunnis along with Shì 'ahs) and of local understandings about how one is to behave and what one is to believe, as a member of a particular social unit - family, lineage, guild, caste, religious community, political party - however defined.

The two themes of this paper are closely related: the multiple, subjective embodiments of emotion in practice create "emotional texture," . . . a way of talking about the changing configurations of affective meanings that ... [individuals] assign to rituals [and music] ... [ [which] emerge from a tension between individual feelings and experiences and the classification of 'emotion' in language and ritual (Wolf forthcoming). 
The classification systems for emotion in this case are primarily encoded in drumming contexts. An example that crops up repeatedly is the wedding, which, being happy tends to be construed in opposition to Muharram. Yet there are interesting points of interpenetration and intertextuality between the two. In examining these points of convergence (and their subjective interpretations) we gain a sense of the emotional texture of these events.

Regarding emotionality in Muharram performance forms, one may speak of simple emotions such as happiness or sadness, or more focused affective modalities such as mournfulness, celebration, tribute, pity, horror, or even Islamic or sectarian altruism. These modalities operate simultaneously. The forms themselves, drumming, recitation melodies, and texts, endure over time and space, while supporting interpretations vary - not only over time and space but even within a specific area among different communities, factions of communities, or individuals. Furthermore, individuals sometimes construe the affective overtones of the constituent parts of a performance (melody, drumming, breast-beating, text) differently.

The geographically comparative scope of this article limits my space for discussing methodology and local contexts in the depth some readers may desire. To make a few general statements, though, the emotional attributions I describe are consciously articulated by the different kinds of performers (drummers and reciters) and other participants I interviewed. In awkward moments, with shy or tongue-tied consultants, I would, often with the assistance of an interpreter, inquire directly about what it feels like to drum or listen to drumming. But often, discussing the phenomenon of drumming itself led individuals to comment on the affective import of drumming and its relation to the occasion. The way in which conversations seemed themselves to gravitate around emotional issues is one of the phenomena I attempt to evoke in the epigraph.

To complement this theoretical and methodological introduction it will be useful to provide additional background on the Islamic community and context I am investigating.

\section{Religious, Historical, Communal, and Geographical Contexts}

Shī $\mathbf{i}$ Muslims are a minority in most Muslim countries except Iraq and Iran, their spiritual heartland; they constitute about $10-15 \%$ of the total $25 \%$ Muslim population in the Indian subcontinent. They share with all Muslims beliefs in the divine origin of the Qur'ān, the prophethood of Muhammad, and the unity of god, Allah. Shī 'i Muslims differ from Sunnis in their allegiance to particular members of the Prophet, Muhammad's family, whom they believe were his legal and spiritual successors. In particular, they give special emphasis to the Prophet's daughter, Fatima; his son-in-law, Ali, the first Imām; Ali's son Hasan, the second Imām; and Hasan's brother Husain, the third. Muslims generally accept the idea that the Prophet was "ma 'su m," or flawless, but only the Shĩ 'ahs attribute this quality to all Imāms. Furthermore, they attribute to these Imāms a quasinuminous quality to which Sunnis object.

South Asian Shì 'ahs extend the length of Muharram from the standard ten days observed in Iran to two lunar months and eight days. Retelling the story of Husain's martyrdom, they also recall scenes from the battle using a variety of dramatic and poignant verbal genres (marsiyah, soz, salam, nauhah), and carry 
battle standards ('alam), tomb replicas (ta'ziyah), and other icons of the Karbala story in processions. In rural areas Shī 'ahs sometimes continue to perform drums as part of their ritual observances as was, apparently, once widely common; in cities, Hindus and Sunnis are usually the ones who perform drums and other musical instruments on this occasion (see, e.g. Census of India 1971, 76-78).

Although this discussion centers around the voices of individuals in these communities whose identities are in a sense preconstituted (as Shī ؟, Sunni, etc.), it should also be noted that many families, especially in the royal lineages of Hyderabad (Andhra Pradesh) and Lucknow, consisted both of Shī $\mathrm{i}$ and Sunni members. A single rājā, for instance, would sometimes maintain both Shī $\uparrow$ and Sunni wives at the same time; the identity of members of these families would crystallize according to situation, often opportunistically. In the famous words of the Nawab, Wajid Ali Shah "of my two eyes, one is a Shia and the other is a Sunni" (Hasan 1990, 217). Outside the urban areas, which are often communally polarized, Muslims are often unable to differentiate between Shī $\uparrow$ and Sunni Islam, and indeed, some individuals maintain an identity that combines Islam with Hinduism; this is especially true in parts of south India. ${ }^{8}$

\section{A Telugu transformation}

In the region of Hyderabad, Andhra Pradesh, for example, the famous Telugu song, "Ashana Ushana," tells the story of a Muslim woman named Bibi who prays to the Hindu god, Śiva, for the boon of a male child. ${ }^{9}$ She gives birth to presumably "Hindu" children, Ashana and Ushana (i.e. Hasan and Husain). As adults these brothers come into conflict with "Muslims" and hide in a well where they are tracked down and killed. ${ }^{10}$ The mother returns to lament over the death of her children.

According to the journalist M. Laxmaiah, Hindus and Dalits of the greater Hyderabad area regard Muharram, which they call Pì rlu Pandaga, as an occasion which commemorates the suffering and proclaims the moral triumph of all dispossessed Indians. ${ }^{11}$ They regard it as a rite of solidarity, representing, in Telugu

\footnotetext{
${ }^{8}$ Deepening our diachronic understanding of the oft-cited cultural mixing in south Indian "folk" Hinduism and Islam, Mines (1975) contrasts the practices of Islamized Tamil Muslims in Madras and those living in smaller cities, towns, and villages in Tamilnadu.

'Bībī means "elder sister," or "woman," but in the Shî '̂ tradition is a reference to Fātima, daughter of the Prophet Muhammad and mother of Hasan and Husain.

${ }^{10}$ It is unclear from where the well symbolism derives. A local tradition in Mushirabad, Hyderabad revolves around a story in which a man was called to a well by the spirits of Hasan and Husain in a dream; he found battle standards there and insisted on being ushered out from the well with three kinds of musical band. From that year forward (early this century) a festive celebration involving drumming, fire walking and possession has taken place at Mushirabad. In Shī '̄i lamentations over the battle of Karbala, poignant moments are devoted to remembering the thirst of the children on Husain's side, who were denied a drink of water from the Euphrates, and the dismemberment of 'Abbās as he tried to carry water in a leather pouch from the river. Perhaps the theme of seeking water has been transferred and transformed from one narrative to the other. See also Parks' account of Muharram with an account drawn from local folklore of a spider spinning a web over the well to hide the Imām from sight (1850:I, 300).

${ }^{11}$ Pirlu Pandaga means the festival of the "pìrs." Pīrs are, properly speaking, Muslim saints or Sufi spiritual leaders, but in this case they are casteless, godlike spiritual beings. Laxmaiah belongs himself to a Scheduled Caste and grew up in a village that celebrates Pị rlu Pandaga. He has devoted more than a decade to documenting diverse celebrations of this festival in the Tel-
} 
"icci puccukōvaḍam," reciprocal give and take, "a little bit of Muslim culture, a little bit of Indian culture, all on one path." ${ }^{12}$ Drumming takes on a special meaning here, because in several parts of south India dalit communities have embraced frame drumming (dappu in Telugu, slightly larger than the parai and tappattai frame drums in Tamilnadu) as emblematic of dalitness. These communities have developed their own rhythms and dances to celebrate Pìrlu Pandaga

\section{2. "Music" in Muharram}

The instruments performed during Muharram vary by location in the subcontinent, but in many places the Muharram ensemble par-excellence is the $\mathbf{d h o l}$ $t \bar{a} s \bar{a}$, or $t \bar{a} s \bar{a}-b \bar{a} j \bar{a}$, comprising the cylindrical drum dhol, the shallow kettle-drum, tāsa and cymbals, jhānjh. ${ }^{13}$ Other important instruments include deep kettledrums (naqārah), frame drums (dappu, especially in the south), double-reed aerophones with conical bore (śahnāi), and sometimes bagpipes or Western marching band instruments. ${ }^{14}$ Some rhythmic patterns and melodies translate across different musical ensembles and exist in regional variants.

The issue of whose place it is to drum and in what circumstances drumming is appropriate raises a general problem. ${ }^{15} M \bar{u} s \bar{\imath} q \bar{\imath}$, music, is not allowed in scriptural Islam, because, in simple terms, it distracts one's mind and senses away

angana region of Andhra Pradesh (See, e.g. Laxmaiah 1998).

12 One should note the convergence of this sort of unification ideology regarding Muharram outside the conservative religious hold of a particular faction, with a trend on the Shī I side, "a tendency to downplay doctrinally contentious issues such as intercession and instead to emphasize both the social usefulness of Muharram and the need for ethical responsibility on the part of the individual participant" (Pinault 1999, 296). See also "Husain's martyrdom and the emotional integration of Indian society" in Hasnain and Husain (1988, 155-6).

${ }^{13}$ The type of $\underline{d h o l}$ that usually accompanies the $t \bar{a} s \bar{a}$ is a cylinder drum, although barrel drums are found as well. Tāsā is also pronounced $t a \bar{s} h a ̄$ or even $t r a \bar{s} a \overline{\text { I I }}$ have adopted the spelling $t \bar{a} s \bar{a}$ here for consistency, even though in particular instances the original source for a quotation might provide an alternate spelling or pronunciation. I choose this spelling because it reflects what is presumably an older pronunciation. The word is apparently of Arabic origin, entering the Indic lexica through Persian. It seems likely that the pronunciation " $t \bar{a} s \bar{a}$ " changed to " $t \bar{a} s h \bar{a}$ " in the process of Hindi-ization. The older version seems to be retained in the Trinidadian "tassa." The Tamil " $t a \vec{c} \bar{a}$ " could be a retention or a reversion (Indo-Aryan "sh" becomes "c," pronounced like an "s," in some Tamil dialects). Pre-Islamic evidence of a similar instrument can be found in the famous Țāq-i Bustān reliefs (590-628 C.E.) of Persia (Farmer 1939). The instruments are made of different types of wood, metal, and in the case of the $t \bar{a} s \bar{a}$, clay. For instance, in the Nizamuddin tradition in Delhi, the $\mathbf{d h o l}$ is fashioned from mango wood and covered with goatskin. The $t \bar{a} s \bar{a}$ is made of clay and covered with the skin of a water buffalo calf.

${ }^{14}$ The double-reed aerophone varies in name and size across the sub-continent. In Hyderabad Deccan and Hyderabad Sindh the instrument played during Muharram is relatively short in length and high in pitch. In the Lucknow area a medium sized instrument is used. Wazir Husain, a sahnāi player originally from the Chowk area (old city) in Lucknow described four types of śahnāi, each of seven holes but differing in length: bar sāj ("big instrument") of 15", gel manjholā ("medium cylinder") of 8", manjholā ("medium") of 6", nafin $\bar{n}$ (<Persian nafīn) 3".

${ }^{15}$ I have had little success obtaining historical sources for the legal status of drumming in subcontinental Islam. Cole provides useful and apparently rare archival references (1989, 113-14; 152). 
from thoughts of God. ${ }^{16}$ In part the issue is semantic: in south Asia, "music" usually means the sound of musical instruments. Shi 'ahs do not usually disqualify unaccompanied tuneful renditions of poetry on musical grounds if the textual genres are closely associated with Muharram. ${ }^{17}$ To perform such genres as marsiyah, soz, salām, or nauhah is not to "sing" ( $g a \bar{n} \bar{a})$, as it were, but to "read" (parhnā) or recite. ${ }^{18}$ But even these genres can be rendered too musically. Judging from the quality of soz in Multan, Pakistan, and its ritual use there, we may infer that Shī 'ahs deem it an acceptable component of the majlis. In Hyderabad, south India, however, soz is not at all developed as a form of recitation and is not encouraged in the majlis. Karrar Qazmi - a Shī'ī soz reciter of Avadhi (i.e. the Lucknow area) background whose family had migrated to Hyderabad - explained that this is because Hyderabadis consider soz too musical. Drumming, like reciting, lies at the juncture of music and non-music, and may be interpreted as one or the other according to circumstance. ${ }^{19}$

Musical or quasi-musical events take place in two distinct types of contexts during Muharram: the mourning assembly (majlis) and processions (julūs). Drumming rarely takes place during a mourning assembly, although it has been used to announce or convene the assemblies. Mourning assemblies can consist of a small number of men or women (always gender segregated), or can be very large, held in public areas, often underneath a tent. All the forms of recitation associated with Muharram may 'e performed during the assembly. Nauhah performance is common during processions, since this metric and tuneful recitation is performed in conjunction with mātam. Although participants may recite mars $i$ yahs as well I have never witnessed processional performances of the oftenlanguid soz genre. Most drumming takes place either during moving processions or outdoors in public gatherings. Mourning assemblies tend to be relatively limited with regard to the affiliation of attendees. Although there are separate Sunni majlises in some places (Hyderabad, Sindh, Pakistan, for instance), most such assemblies are strictly Shīī.

Still, many people from many different backgrounds participate in Muharram. The differences in background and approach of these participants sometimes lead to remarkable, but temporary, manifestations of intercommunal harmony, and they sometimes lead to violent clashes (Hasan 1997; Masselos 1982). Communal conflict has been one of the causes of impoverishment of some Muharram rituals, including drumming, and drumming has been a catalyst for continued conflagrations. ${ }^{20}$

\footnotetext{
${ }^{16}$ The status of music is the subject of an ongoing debate in Islamic legal circles; the contours of the debate vary by region, historical period, sect, and school. See Nasr's overview (1997), Lois al-Faruqi's taxonomy (1985), and Roy Choudhury's (1957) scriptural evidence in Arabic. This latter is of specific interest in addressing the Shī $\uparrow$ situation and the study of music in south Asian Islam.

${ }^{17}$ This important distinction between "music" and tuneful recitation of a sacred text is rooted in Islamic understandings of Qur'annic recitation, which shares musical parameters but is nevertheless, by definition, not music (see, e.g., Nelson 1985, 153-7).

${ }^{18}$ For a fuller discussion of these forms see Qureshi (1981).

${ }^{19}$ See also Sakata, who found that in Afghani musical terminology the sound of the drum is less musical than that of a stringed instrument $(1983,47)$.

${ }_{20}$ Abdul Halim Sharar ascribed the impoverishment Muharram rituals (some involving drumming) to Shī'ah-Sunni conflicts early in the twentieth century $(1994,151)$. Nayyar Masud,
} 
Since cultural interpretations of ritual drumming depend on interpretations of drumming contexts, in this case Muharram, it will be useful to summarize how south Asian views on Muharram translate into a variety of emotional or affective modes, and serve in some capacity for religious and cultural identity. In one Shì ' view, by remembering the events of Karbala, and dissolving personal sorrows and triumphs into the greater sorrows and triumphs of the Prophet's family members, one may in effect petition the martyrs of Karbala to intervene on one's behalf, thus bringing one closer to god. This remembrance is embodied in forms of self-denial, effusive crying, and sometimes self mortification. ${ }^{21}$ As mentioned earlier, the fact that many Muslims consider the battle of Karbala to have been a victory for Islam infuses the atmosphere with pride, vigor, and Islamic altruism. ${ }^{22}$ Non-Muslims not only participate in Muharram, but also organize their own celebrations, in some places transforming the Karbala narrative significantly, as in the Telugu example cited above.

Just as the greater Muharram phenomenon extends well beyond what any particular Shì $\mathfrak{1}$ cleric might consider theologically appropriate, so too do the semiotics of ritual drumming transcend Muharram as a particular context. Consequently, as mentioned, I will consider in broad terms three ways in which drums might signify: 1) the association of the drums, as objects, with special contexts, 2) the ways meaning is attached to specific patterns articulated on the drums, and 3) the aesthetics of what might be called the expressive potential of particular drums and drumming styles, through such features as timbre and tempo.

\section{Enduring Contextual Associations}

Certain drums have the potential overwhelmingly to suggest certain contexts to particular populations in particular places. A well-known example from south India is the parai frame drum, performed by the eponymous pariah community, the paraiyar. The drum's association with funerals and its cow hide membrane links it broadly with death (Moffatt 1979, 112-13). A double-waisted drum called the pampai is strongly associated with spirit possession, both disgruntled spirits of the dead $(p \bar{e} y)$ and ferocious goddesses; this association is enhanced by the

Lucknavi Persian scholar and himself a Shī 'ah, also attributed the decline in drumming among Lucknow Shī 'ahs to the rise in tensions between the communities (pers. com. June 98). These role differentiations served to further exacerbate intercommunal tensions. A muhäjir soz reciter now living in Karachi recalled 1920s' clashes between Shī'ahs and Sunni in Lucknow: when their respective processions crossed, Sunni drumming became one of the forceful signs of difference that helped transform intercommunal tension into violence. Variations of these reciprocal processes of role differentiation, increased tension, and decline in ritual traditions have occurred in other parts of the sub-continent later this century. Conflicts have involved Shī 'ahs, Sunnis, Hindus, and Scheduled caste communities. The historian, Mushirul Hasan, observed clashes over musical performance in Calcutta Muharram processions, 1954-55 (pers. com. 1998). In Shī 'ah-dominated Jaggadevi (Dharmapuri district, Tamilnadu), Scheduled Caste drummers no longer perform for Muharram because of rifts between themselves and higher caste Hindus. For social reasons, the Shì 'ahs have assimilated upwards in the caste system.

${ }^{21}$ See Pinault (1999) for a discussion of mātam and the problem of intercession in Shĩ Y Islam. See Nizami $(1989,7)$ for a statement of a Sufi belief that Muhammad's family is spiritually present during Muharram and accept offerings of the devoted.

${ }^{22}$ See, e.g. Schubel (1993, 135-36); one of his Shī 'ah informants remarked, however, that "the time for celebrating that victory is not while one is remembering his [Husain's] death." 
unusual growling sound produced by rubbing a curved stick on one of the drum heads. Other drums call to mind auspicious occasions; the large barrel shaped version of the $d h o l$ in many parts of India calls to mind the superb playing skills of performers from the state of Panjab, and more specifically the ubiquitous bhangra rhythmic pattern played at weddings and other festive occasions.

\section{1. Ḍhol-tāsā}

Although there are exceptions to the above associations, the fact that strong associations are formed at all is important. Similar processes of association link

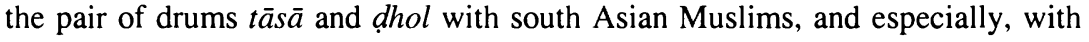
Muharram. ${ }^{23}$ Poems, paintings, and accounts such as that of Sharar (1994) suggest that the shallow bowl-shaped drum, the $t \bar{a} s \bar{a}$ and the cylindrical drum, the dhol, have been associated with Muharram in India for at least a hundred and fifty years and probably much longer. ${ }^{24}$ Now dhol-tāsā ensembles are spread widely in India and are especially popular in Trinidad (Korom 1994a), one of the several regions in the Caribbean where Indian laborers began to migrate beginning in the late 1830 s.

The most valuable historical description of $t \bar{a} s \bar{a}$ performance is that by $\mathrm{Ab}$ dul Halim Sharar (1860-1926), a journalist and historian who hailed from a family of literary and religious scholars associated with the court of the last Nawab of Lucknow, Wajid Ali Shah. ${ }^{25}$ He described six kinds of wedding and processional bands in the late $19^{\text {th }}$ and early $20^{\text {th }}$ centuries, all of which survive to a lesser extent today: "dhol tasha . . raushan chauki [two śahnāi players and one percussionist with two drums strapped to his waist] . . naubat . . narsi and qurna, horns and trumpets; danka and bugal, large kettle drums and bugles, and

\footnotetext{
${ }^{23}$ For instance, in Udaipur, Rajasthan, the tāsā is popularly known as arabī tāsā; this practice of naming, reflected also in exhibit captions in the Bhartiya Lok Kala Mandal, links the instrument to an Islamic homeland on the Arabian peninsula. See also Capwell's study of the Indonesian gambus as an Islamic cultural icon that provides an indexical link to an Arab homeland (Capwell 1995).

${ }^{24}$ Mica paintings of $\underline{d h o l}$ and $t a \bar{s} a \bar{~}$ players, c. 1850, are reproduced in Korom (1994a, 74-5).

Sayyid Sarir Ahmed Nizami, a Karachi-based $t \bar{a} s \bar{a}$ player whose family was associated with the Nizamuddin shrine in Delhi, offered the exaggerated claim that his family tradition of $t \bar{a} s \bar{a}$ playing was 450 years old. Pushing the date further back, he expatiated that the thirteenthcentury Sufi poet and disciple of Nizamuddin Auliya, Amir Khusrau, created (ijad) today's tāsa "rāgs" (i.e. patterns). Across the subcontinent, oral histories vaguely associate dhol-tāsā performances with the congeries of Muharram observances that Timur was said to have introduced to the subcontinent at the end of the $14^{\text {th }}$ century (97//15, Karachi, Jacob Lines), though this seems doubtful (see Schubel 1993, 110). According to Ali Abbas Nizami, Timur introduced the practice of carrying and displaying holy relics, but the ruler of Delhi and "lover of the saints," Bahadur Shah Zafar (1775-1862), introduced the practice of accompanying this display with "playing and singing" (bāje gāje ke sāth) as a means of protecting the relics from the "filthy" mobs of people who would throng Muharram processions (Nizami 1989, 9-11).

${ }^{25}$ The following references and quotations from Sharar's work are taken primarily from the translation by Harcourt and Hussain (Sharar 1994); in instances of terminological ambiguity, particularly from a musicological standpoint, I have returned to the original Urdu (Sharar 1965). I thank the Urdu scholar Amy Bard for helping me locate these passages and clarifying the translations.
} 
Scottish bagpipes, a British instrument of increasing popularity" (Sharar 1994, $150-51)^{26}$

Lucknow bands of the period featured three or four $\underline{d h o l s, ~ o n e ~ t o ~ t h r e e ~} t a \bar{s} \bar{a} s$, and a single pair of cymbals, jhānjh. Sharar strikingly suggests that jhänjh military bands from Delhi were combined with $t a \bar{s} a \bar{s}$ in Lucknow, perhaps

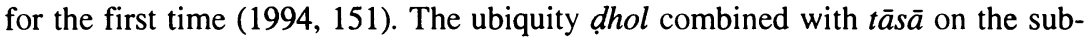
continent leads one to wonder the extent to which, if this was the first time such a combination came about, modern day ${ }_{\text {hol }}$-tāsa ensembles can trace their genealogies to an earlier Lucknow tradition.

Sharar describes the musical style of these Lucknow ensembles, in which $t \bar{a}$ $s \bar{a} s$ are "compulsory" (lāzmin) and "dhols are absolutely never played without them" (1965, 218):

They [tāsa players] establish the rhythm/tempo (lay qa' 'im kartā hai) and the dhol players go on following them. In the tāsa playing method (sifat), the beats should fall (zarb paren) with such rapidity that one stroke (qur'ah) cannot be distinguished from another. Rhythmic patterns (lay) and compositions (gat) are produced from these continuous and incessant strokes, which are descending and ascending/low and high (nasheb-o-faräz), and from the contrasting registers of the drums (zer-o-bam). In Lucknow these bandsmen (bajānewäle) were so skilled that the dhol players from some other cities cannot [i.e. would be ashamed to] play in front of them (Sharar 1965, 218; translation adapted from 1994, 151).

Sharar also describes musical contests during Muharram, in which expert musicians, among whom "the tāsa players were the most skilled," performed for hours at a time "issuing challenges to all." Wajid Ali Shah, the last Nawab of Lucknow, regarded until recently as the apotheosis of Avadhi royal decadence, was a well-known composer and musician. His ability to perform $t \bar{a} s \bar{a}$ is affirmed by Sharar, who witnessed him leading a procession on the $7^{\text {th }}$ of Muharram in Matiya Burj, the Calcutta neighborhood to which he was exiled by the British.

Despite the royal associations of drums, especially the naqārah, and the occasional Wajid Ali Shah, south Asian drummers tend to rank low in both musical and social hierarchies (although there are, as always, exceptions). They tend to be paid less than singers and performers of melodic instruments, and their salaries are often filtered through the soloist whom they accompany. If emotional attributes adhere to drumming, so too do negative social attributions of class. These are not necessarily related, except in elitist stereotyping of "low class fellows"

\footnotetext{
${ }^{26}$ I was unable to confirm reports that a type of band bearing the name raushan chauki continues to perform during Muharram in the town of Amroha in Uttar Pradesh. The type of band Sharar terms raushan chauki appears simply to have been a portable naubat ensemble. In my fieldwork, I observed in Mahmudabad (Uttar Pradesh) that the naubat musicians who play several times a day in the Raja's palace also accompany important Muharram processions. During the chehlum (fortieth day of mourning) procession in 1998, the youthful naqärah player used his hands to perform the naqärah's constituent drums, $j i l$ and $d u k a r$, which were tied around his waist; sitting in the naubat khānah he performed these drums using sticks (see notation, p. 26). The śahnāi player performed melodies based on sung elegiac poetry. Two alternating drone śahnāis accompanied him; one held the tonic; the other, oddly, held a pitch a perfect fourth below.
} 
who are unable to comport themselves with dignity - i.e. to be solemn at an occasion of mourning.

\section{Change in use of drumming: Association with mirth}

Changing ideas about what is emotionally appropriate, increasing divisions along community lines, and class aspirations are among the factors that have led to a decline not only in drumming but other celebratory aspects of Muharram as well. Such changes are a function, in part, of local circumstances. Masselos has argued, for instance, that changes in the Bombay Muharram were "never due only to the impact of ideas or the view of custom," and were never total, but depended very much on circumstance, social organization behind Muharram, and "the enforcing power of police administration" $(1982,62)$. Other aspects of change would appear to follow systematic trends, such as those suggested by Aubrey Cannon. He has argued that mourning rituals, cross-culturally, oscillate between periods of ostentation and restraint: initially, competitive ritual elaboration serves purposes of social and economic display; later, "elaboration becomes increasingly associated with lower status categories," and rituals begin to take on a restrained, austere character (Cannon 1989, 437). Similarly, Nita Kumar noted that in Banaras of the late 19th and early 20th centuries a "new rationalism and Victorianism" affected the "position of the courtesans, public celebration, lewdness at Holi, love of mud" etc. and repositioned "each of the major entertainments of Banaras" as the "province and symbol of the lower classes" (Kumar 1988, 234).

Still, at some level a cultural logic can be seen to inform these changes; in this case it hinges on the possibility of interpreting a potentially ambiguous phenomenon one way rather than another. In one view, drumming constitutes a morally empty gesture in ritual, an "instrumental" means for gathering crowds; in another, it is an expressive form worthy of criticism as "music." These views are not entirely independent of the ways in which the drums are actually played, i.e. strictly repetitive patterns are associated with the former and skillful improvisation with the latter. Nevertheless, this ambiguity creates an opening for actors to interpret drumming content using information gleaned from performance context.

Although it is difficult to generalize, I have found that in urban areas more so than rural, Shī 'ahs in India and Pakistan feel that any object or behavior indicative of happiness or celebration is inappropriate for the mournful occasion of Muharram. Wherever musicians perform $t \bar{a} s \bar{a}$ for occasions of mirth, such as weddings, these Shī 'ahs customarily object to its performance during Muharram. They believe drumming is for fun, celebration, it is khush $\bar{l}$, and Muharram is an occasion of seriousness and sorrow, or gham. The drum itself becomes imbued with the qualities of a favored context; put in another way, it is not uncommon for persons of many south Asian communities to believe that instruments such as the $t \bar{a} s \bar{a}$ should have a particular, limited context. Although people of many cultures engage in drawing such associations, the process takes on a special meaning in the context of Islam, in which "analogical reasoning" (qiyās) is a codified mode of legislation. ${ }^{27}$

${ }^{27}$ Qiyās means, "concluding from a given principle embodied in a precedent that a new case falls under this principle or is similar to this precedent on the strength of a common essential features called the "reason" " (Rahman 1979, 71). For example, according to "Abdul haq Dihlwi, 
A similar sort of analogical thinking can be discerned in the process by which anti-drumming Shì 'ahs (again, usually urban) have interpreted the phenomenon of Sunni participation in Muharram through drumming: in their view, Sunnis drum during Muharram because they consider Muharram to be joyous. This underscores the idea not only that drumming should be limited to particular contexts, but also that the drum belongs to particular communities. It also articulates the theme that Muharram is shared by more than one community, each with its own interpretation. From the standpoint of understanding the interplay between emotions and cultural and musical processes it is interesting to observe the manner in which Shī 'ahs use the field of emotion and the practice of drumming to distinguish their understandings of Muharram from those of Sunnis. ${ }^{28}$

\section{Complementarity and conflict: Intercommunal drum roles}

In urban multi-community observances of Muharram, Shī'ahs sometimes incorporate Sunni or other community participants into their own rituals, often while finding symbolic or physical means for expressing moral distance from those communities. These relationships are always in flux, as the following examples illustrate.

In Delhi, a well-known Muharram procession starts from the Sufi shrine of Nizamuddin Auliya. Although the $\underline{h} h o l$ and $t \bar{a} s \bar{a}$ drummers who perform in that procession now are Hindus, historically Sunnis and Shī 'ahs also drummed. Some of the Shi' $\bar{i}$ and Sunni Muslims whose families were connected with this shrine before the partition of India and Pakistan now live in the Jacob Lines area in Karachi, where I interviewed them and recorded their repertoire. ${ }^{29}$ The subject of Muharram drumming is a sensitive one in that neighborhood; so much so that the party of religiously conservative students, the ISO, at one point threatened violent consequences should the drummers demonstrate the Muharram rhythms for me outdoors. $^{30}$ Even more sensitive was the idea that Shí 'ahs might be drummers

in early Islam, jars were condemned because people drank wine in jars, and music was prohibited because it was associated with dancing girls and wine (Roy Choudhury 1957, 63). However, early Imamite evidence suggests that analogical reasoning, along with other forms of logical reasoning practiced in other branches of Islam, was not supported in early Shī 'ism. See discussion and quote attributed to sixth Imam in Moezzi $(1994,14)$.

${ }^{28}$ According to Sunni drummers I interviewed in the Kārāwrī mohalla in Udaipur, Rajasthan, Sunnis are also not supposed to be happy during Muharram, but by virtue of "tradition" they continue to drum. Yet they denied any commemorative function of drumming in relation to Karbala. Schubel provides further illustrations of the apparent differences in emotional approach to Muharram among the two communities, "Sunni juluses [processions] carry about them this celebratory atmosphere ... drums are beaten. Brightly colored and ornate ta'ziyahs are marched cheerfully through the streets of the city ... [whereas] Shī i processions . . . are in a very real sense funeral processions" (Schubel 1993, 135-6; see also Census of India 1961, 15-16 and passim) Pinault cites a sixteenth century Qur'ān commentator who "defines a Muslim community not in terms of doctrine but rather in terms of ritual activity and emotional disposition" (Pinault 1999, 291). Compare Lutz $(1988,223)$ who discusses the role of emotions in other forms of "alienation . . . in the estrangement of the person from other persons."

29 According to Ali Abbas Nizami, author of the pamphlet outlining the family's history and religious practices, one Sayyid Kazim Ali returned to Delhi after partition to collect the designs for ta'ziyahs, 'alams, etc. used during Muharram at the Nizamuddin shrine. Beginning in 1954, the Karachi emigrants began to replicate the rituals from Delhi. Participants continue to make monthly donations to the shrine in Delhi (Nizami 1989, 13).

${ }^{30}$ These interviews and recordings were conducted during the month of Muharram, but after the 
themselves. The information I received was often contradictory, reflecting a combination of the community's ambivalence about this subject and some degree of historical confusion. I have gathered the following: Shī'ahs and Sunnis formerly incorporated multiple ta'ziyahs in their processions from the Nizamuddin shrine in Delhi. Generally, tāsa drumming accompanied Sunni ta'ziyah(s), but in one instance it also accompanied a Shī'ī ta'ziyah, that brought out by Vajid Khurshid Ali, who migrated to Pakistan before partition and died sometime in the 1950s. ${ }^{31}$ Apparently only one Shī'ah, Ansar Husein, who they were quick to point out is now dead, used to play the $t \bar{a} s \bar{a}$.

Now Shī'i and Sunni muhäjirs (Indian Muslims who fled during partition to what became Pakistan) live side by side in this Karachi neighborhood; Shī 'ahs invite Sunnis to perform during Muharram. Their repertoire is identical to that performed by the Hindu musicians in Delhi into whose hands the post-partition Nizamuddin Muharram drumming tradition has now passed. According to a pamphlet prepared by a member of the Nizami family, looked upon by participants as preserving canonical information about their tradition,

Devotees' hearts are full of grief during these days of the great martyrdom. Keeping in view the purpose of the martyrdom, this procession, of which the ta'ziyah is a sign, is taken out with a mixture of happy and sad feelings. Respect and reverence prevails upon the procession throughout (Nizami 1989, 3).

The inclusion of $t \bar{a} s \bar{a}$ ensemble in the procession, according to this pamphlet,

can be a sign of happiness over the fact that by giving his sacrifice and keeping Islam safe from Yazidiyat [practices conforming to those of the evil Yazid, whose armies slew Husain] and un-Islamic deeds, Husain saved the boat of the umma [the Muslim community] and [arranged its] salvation. What can be a greater happiness for us? $(1989,13){ }^{32}$

The writer betrays defensiveness regarding orthodox Islamic criticisms of his family's Sufi practices and seeks to diffuse accusations that his people are imitating Shī'i practices; but it affirms the Nizami community's belief in the intercessory power of Imām Husain and Nizamuddin Auliya. Criticism of Shī 'ism and some forms of Sufism are particularly salient in Pakistan: it is an Islamic state, but the prevailing question, "whose Islam is it?" remains. The syncretic aspects (intra-Islamic or Islamic-Hindu) of Indian Islam are less accepted under

first ten days, during which such drumming is conditionally tolerated. In the course of discussions with these musicians I learned that on other occasions such as the Sipah-e-Sahaba, who would use whatever means necessary, including the issue of functional and cooperative Muharram drumming, further to drive a wedge between Shī 'ahs and Sunnis.

${ }^{31}$ Vajid Khurshid Ali was apparently a tabla player who performed on Pakistan radio, although I have not been able to confirm this.

${ }^{32}$ A similar tension between interpretations of Muharram as mournful and festive is maintained in Trinidad, where Shair Ali, reportedly a descendent of one of the founders of the Hosay (Muharram) tradition on the island, wrote in the Trinidad Guardian, "the atmosphere of elation which is generated by those Muslims who participate in the Hosein festival is definitely justifiable. . . Hosein gave his life for Islam. To live was the death of Islam, to die was its preservation, so he died to protect Islam and his death should be marked both by sorrow and happiness" (cited in Korom 1994b, 146). 
the national religious ideologies of Pakistan; despite the right-wing turn in Indian politics, India's commitment towards "unity in diversity" persists in some measure.

Still, the Chistiya Sufi order, to which Nizamuddin Auliya belonged, remains relatively catholic in outlook - even in Pakistan. The Nizamis regard Muharram as a kind of "urs, the celebration of the death anniversary of a saint. The word means "wedding," but it is really the apotheosis of a wedding, commemorating the union of a saint's spirit to the divine. This creates a special, and felicitous, kind of intercontextuality between a "wedding" and Muharram. Since such an occasion calls for celebration, mournfulness, rather than happiness, becomes the problematic emotional modality. ${ }^{33}$ At one point, in a mode of continued defensiveness, Nizami writes

let it be clear that in the family no such marsiyahs, saläms, or nauhahs, are recited with mournful language. Nor is there any subject which belittles the majesty of the Prophet's family $(1989,9)$.

This denial of mourning might be left open to question, as we examine some of the texts represented through drumming in part IV.

Despite attempts by Sufis of the Nizami family to disidentify with Shī 'ahs, Shī 'ahs nevertheless participate in the tradition of Nizami Muharram observances (and its transplanted version in Karachi) and weep. And yet there is a certain discomfiture on their part surrounding the performance of drums. Although Shī 'ahs perform mātam (literally "mourning" but in this instance, breast beating) to the sound of the drums, ${ }^{34}$ and they understand the drum sounds themselves as communicating the occasionally appropriate verbal messages we will consider in part IV, they do not choose to embody the rhythms in the same way these (Sufi) Sunnis do: they beat upon their own bodies, not upon the drums, and they render nauhahs and sometimes marsiyahs when the processions pause and the drumming ceases. Sunnis (in this instance) beat upon the drums, not upon their bodies, and remain silent while the Shī 'ahs recite.

\section{Màtam: The rhythmic pattern and the bodily practice}

In Muharram drumming traditions, including that of Nizamuddin, the drum rhythms are unique to the occasion and bear special names. Mātam is usually one such name, although the rhythm to which this refers varies locally. When a Sunni $t a \bar{s} \bar{a}$ player was performing a mātam rhythm during a Shi' ${ }^{\prime} \bar{i}$ chehlum procession in another location, Mahmudabad, Uttar Pradesh, I asked him if he, as a Sunni, ever participated in mätam (breast beating). He responded that to perform the mätam rhythm itself constituted a performance of mätam (in the larger sense of mourning). ${ }^{35}$ The complementarity in processions is often viewed this way: drumming

\footnotetext{
${ }^{33}$ Although an element of mournfulness also pervades north Indian and Pakistani weddings, especially on the bride's side (e.g. Grima 1993, 52-7; Raheja and Gold 1994, 78-9), this element of emotional texture is, in a sense, kinship generated and, therefore, irrelevant to the commemorative type of spiritual "wedding" or "urs.

${ }^{34}$ An example of how the breast beating and chanting of "Husain Husain" fits with the drumming of mātam can be found on my recording of 8 June 1997 (97/D1 1; 97/V10 [video]).

${ }^{35}$ This is an example of an extremely low status (and apparently impoverished) performer participating in Muharram. Unlike the naubat musicians, who announce the hours from the raja's palace and play nauhah melodies, the
} 
for Sunnis accomplishes the same thing as activities such as mätam, breast beating, or reciting of nauhah or marsiyah among Shī 'ahs. It is a mark of distinction, exemplifying the identity politics characteristic of the subcontinental Muharram phenomenon (Masselos 1982; Kumar 1988, 213; Pinault 1992).

David Pinault has argued that mātam, in the form of gentle or vigorous breast-beating, or the more impassioned flailing with sharp implements, is characteristically Shī $\mathbf{1}$ - i.e. Sunnis do not engage in this practice (Pinault 1992, 99120). Among other things, this difference underscores each community's position vis-à-vis the authority of the Prophet's lineage: since Sunnis do not invest authority exclusively in members of the Prophet's family (i.e. they esteem the Caliphs, not the Shī 'ì Imāms) they are perhaps less physically/emotionally invested in painfully recreating the moment in history that for Shī'ahs reinforces the character and strength of the Imāmate. Yet, it is apparently not the case that Sunnis completely avoid, in all parts of the subcontinent, some corporeal forms of $m \bar{a}$ tam. ${ }^{36}$ In Multan, for instance, there are dozens of ta $a^{\prime}$ ziyahs, both Shī $\overline{1}$ and Sunni, and one can neither discern from the presence of mätam nor from the presence of

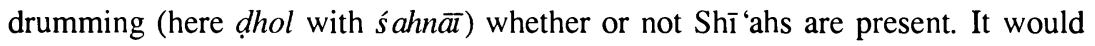
appear that at least some of the Shì 'ahs in Multan accept the ritual appropriateness of these instruments in the procession. Like mutual performance of drumming (or at least its tacit acceptance), intercommunal mātam is perhaps more common in areas in which Shī 'ahs and Sunnis are relatively cooperative during Muharram.

But when cooperation is less pronounced, drumming, its volume not easily ignored, sometimes serves as a powerful sign of difference. Shī 'ahs have on occasion reacted negatively and with passion to the sound of Sunnis or Hindus drumming. Beyond feeling it morally objectionable, Shī'ahs sometimes find drumming objectionable on purely rhythmic grounds - unless conscious effort is made at coordination, the rhythms on the drums may conflict with those of poetic recitations and/or breast beating. Thus the manner in which drumming is incorporated into an occasion can constitute a partial performance of the unity or separateness of communities. ${ }^{37}$ The śalınā nawāz, Muhammad Anwar, in Hyderabad, Andhra Pradesh, explained how, in the late 1980s, Shī'ahs suddenly of their own accord,

repertoire of only a few rhythms. Although tāsã players are in no sense central to this particular Muharram custom, they are apparently "traditional," having participated for many generations. I was not given access to the historical răbakārs in the Mahmudabad estate; these are one page documents specifying the customs to be followed each year.

${ }^{30}$ Sunni participation in mätam seems to be implied in Nita Kumar's account, "all the Sunnis of Banaras, except the Wahabis, celebrate Moharram" by, among other things, carrying "a shoulder-borne taziya, surrounded by crowds of mourners who chant, cheer, lament, and physically torture themselves to express their grief" $(1988,212)$.

${ }^{37}$ See also Schutz's idea of "tuning in," a social relationship "founded upon the partaking in common of different dimensions of time simultaneously lived through by the participants" (Schutz 1964, 177). Turino states the case strongly, "when music makers and dancers are in sync, such signs move beyond felt resemblances to experienced fact or social connections and unity" (Turino 1999, 241). One wonders the extent to which, in the situation I have described, being "in sync" instantiates a genuine feeling of unity or merely registers a degree of mutual accommodation. 
forbade [us to play] because they said it was "disturb"ing [he used the English word here] their mātam. At ashurkhāna nāl-e-mubārak there is mātam; individual groups would come there. ${ }^{38}$ They stopped it because it was a disturbance. But then they understood that we were playing nauhahs and marsiyahs, playing on the "base" of the ashurkhanna [i.e. maintaining the spirit of the occasion]. Now they are happy [that we are playing, not cheerful about the occasion] and they bring money to give us ... (98/Hy/In 1$)$

\section{A test case}

Instances such as those above suggest an array of logical possibilities that I present here by way of hypotheses: 1) When a single common element such as a drum is associated with two occasions whose moral themes are seen as conflictive, a wedding and Muharram for example, that element could at some juncture, probably one of social or cultural distress, be scrutinized, reevaluated, and possibly removed from one or both of the two occasions; 2) Similarly, when an element such as a drum is considered integral to an identity-defining ritual of community $\mathrm{A}$, but is used or performed by the members of community $\mathrm{B}$, it may, in cases where communities $\mathrm{A}$ and $\mathrm{B}$ are in conflict, be morally reevaluated. Although I stated these possibilities in a generic fashion, we might also wish to know what might be special about a drum as opposed to other ritual objects. The special expressive properties of drums are considered in part V.

I realized while conducting fieldwork that these hypotheses could be subjected to modest ethnographic tests. What would happen if Shī'ahs lived without significant religious or political rivalry from Sunni Muslims, and if the $t \bar{a} s \bar{a}$ were not primarily associated with festive occasions? Shī 'ahs constitute a local majority in the small town of Hallaur (Basti district, Uttar Pradesh). Considering the $d h o l$ and $t a \bar{s} \bar{a}$ to be unremittingly dolorous, no Shī 'ah in this town would countenance using these drums for any purpose other than memorializing the battle of Karbala. Since the $t \bar{a} s \bar{a}$ is associated only with Muharram here, and not with weddings, and since Shī 'ahs are not in conflict with Sunnis, there do not seem to have been the same impediments to Shī 'ah involvement in Muharram drumming (Sunnis, Scheduled Caste and Backward Caste Hindus also participate, but under a Shī ${ }^{\top}$ aegis). ${ }^{39}$ In fact Hallauris are proud of this tradition, offering cassettes of Muharram drumming for sale alongside other locally produced recordings of occasionally appropriate sung or recited poetic genres. The practice of drumming

\footnotetext{
${ }^{38}$ This would appear on the surface to be a somewhat unusual example of musical instruments being used at a mourning assembly. An ashurkhāna is a kind of shrine to a Shī Imām. Since

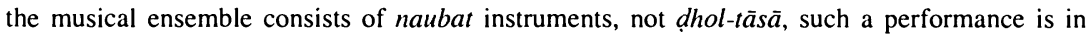
keeping with the more general association between naubat ensembles and royally sponsored institutions (palace, dargah [Sufi shrine] etc.). This particular ashurkhanna is famous for the yearly musical event and is in that sense unique. To my knowledge, no such shrine in south Asia is similarly famous for annual performance of dhol-tāsa .

${ }^{39}$ Parts of Sindh where Shi 'ah-Sunni conflicts are minimal provide similar illustrations. In Hyderabad, Sindh, for instance, Muharram music is performed by hereditary musical specialists called manganhars, composed both of Shi 'ahs and of Sunnis. In processions, mātam (there performed about the head) is well coordinated with the rhythmic patterns performed on one or more $d h o l$ and nauhah melodies performed by a group of $s \bar{u} m \bar{a}$ players. The $s \bar{u} m \bar{a}$ used in this case is a very short one, producing a shrill sound. See section V.1 on timbre and tessitura, below.
} 
is embraced within the communicative framework of verbal and ritual arts. As Sayyid Shakkil Haidar Rizvi (age 38), tāsā player since the age of ten, remarked,

From the sound of the drums, the pain of Karbala comes to their hearts; when they contort their faces, about to weep, then it becomes clear [to others] what is being commemorated ... [we play to] disseminate the message of Husain (pers. com. Oct. 1998).

Rizvi's variation on the common interpretation of drums as announcement suggested that the very presence of processional drumming would attract attention and cause children and onlookers to ask, "why are you playing the drums?" This would provide the opportunity for those more knowledgeable to relate the story of Karbala and invite the interlocutor to experience the tragedy of the narrative viscerally. We have seen that in other regions the fervor-inducing potential of drumming has been interpreted in other contexts to represent Sunni jubilation rather than Shī'i sorrow. Haidar Rizvi perceived no ambivalence, expressing his sentiment that Muharram drumming is " $101 \%$ gham (sorrowful)." There are two kinds of josh (fervor), he explained. That of masti (intoxication in the manner of some Sufi sects), when emotion builds up so far as to cause one to become behosh (crazy/unconscious/intoxicated), is haräm (forbidden); the other type of josh occurs when drummers become so engrossed in playing that they feel Allah is helping them to propagate the message of Husain, and tears form in their eyes.

In concluding this discussion of drums as signs of emotion, community, and context, it may be useful to recall a legend from the nearby town of Uttaraula, which hosts a similar tradition of Shīi drummers. It is said that a few generations ago, Kanvar, the Rāja of Uttaraula, owned a magical daf (frame drum) which used to spontaneously issue forth appropriate rhythms according to whether the occasion was happy or sad. One day a person of Scheduled Caste background recall the ubiquitous connection between Scheduled Castes and drums, especially frame drums, throughout the subcontinent - ventured to seize the instrument and perform upon it. The instrument disappeared and was never again seen.

This story is not to my knowledge consciously used either for ritual elaboration or for generating other forms of symbolic action, but it hinges on the relevant parameters of the present discussion: a drum with an Islamic history, the daf, was formerly associated with both joyous and dolorous occasions. Through the intervention of a social-cultural other, a Scheduled Caste person who could also claim a cultural connection with this drum, the drum disappears. It no longer mediates, magically, between the sad and the happy; it no longer plays itself; it no longer exists at all. Although this story does not suggest "a clear-cut strategy for arriving at culturally defined success" it does present something of a "key-scenario" (Ortner 1979, 96).

\section{How Meaning Accrues to Drum Patterns}

I shall proceed now from a discussion of the drum's associations to the ways in which meaning is attached to its rhythmic patterns. I would like to draw attention to two: One is the potential of a rhythm to communicate through reference to previous contexts and the other is its potential to denote speech. 


\section{Reference to previous contexts}

Rhythmic patterns, often called mātamī or muharramī, have been performed year after year in conjunction with Muharram rituals and come to serve as indexes for them. Although the mātami rhythmic patterns spur some listeners to reflect upon Husain's martyrdom, for others they may, like the nauhah texts recited during the performance of mātam, "evoke ... the liturgical commemoration of that event in the present." Both, perhaps, "evince admiration for mātam in its most spectacular and excessive forms" (Pinault 1999, 305). As the tāsa player in Mahmudabad remarked, drumming mātam is performing mātam. The interreferentiality of beating upon the drums and the body is established phenomenally through the copresence of drumming and breast beating, and reinforced linguistically in the process of naming the rhythm mātami .

The mātami pattern that members of the naubat ensemble perform in Mahmudabad is a brief pattern known also as " $1 / 2$ rhythmic pattern" ( $\bar{a} d h \bar{a} t \bar{a} l){ }^{40}$ To this rhythmic framework, śahnāi players perform nauhah melodies said to derive from those being recited at that moment during a procession; I have observed the sahnā player choosing melodies without actually checking what the nauhah reciters were rendering, however. In the naqār khānah, the siann̄a players choose melodies according to the appropriateness of the corresponding räga to the time of the day $\rightarrow$ a practice also followed by their counterparts in Hyderabad, Andhra Pradesh, and typical of such ensembles all year around. ${ }^{41}$ Thus, although the individual melodies are suited to the occasion of Muharram by virtue of their direct correspondence to tunefully chanted poetry, their musical classification according to rāga has virtually no connection with Muharram. Rather it relates to the diurnal cycle of musical performance which is generally associated with this type of musical ensemble. It is the least variable and arguably least "musical" aspect of the performance that indexes Muharram unequivocally, the mātami tāl, performed on the left and right drums (dukar and $j \bar{\imath} l$ ) of the naqārah as follows:

\begin{tabular}{|c|c|c|c|c|}
\hline Vocalizatic & & ta la & & jha la \\
\hline Pulses & $1 \ldots$ & 2. & $3 \ldots$ & 4. \\
\hline dukar & 1. & $\ldots$ & I.. & $1 \ldots$ \\
\hline$\overline{j l} l$ & $\ldots$ & 1.1 & . & 1.1 \\
\hline or a faster & & & & \\
\hline dukar & $1 \ldots$ & $\cdot$ & I. & $\ldots$ \\
\hline $\bar{\jmath} l$ & . . & 1.1 & . & 1.1 \\
\hline
\end{tabular}

The repeated association between this pattern and the Muharram context, rather than any intrinsic character of the rhythmic content, creates meaning for most listeners. But this particular kind of indexical association is not the only possible way that drum patterns may signify, for some of these have the potential to communicate lexically. This phenomenon, widely studied in Africa, has seldom been noted in south Asia. Frank Korom's hypothesis that, in Trinidad, $t \bar{a} s \bar{a}$

\footnotetext{
${ }^{40}$ The dhol-tāsa ensemble is socially, ritually, and musically distinct from the naubat; in most places the status of the former's members is lower than those of the latter.

${ }^{41}$ A naqār khānah or naubat khānah is a building or a tower from which double-reed and kettle drum players project their music, usually according to the watch. See photograph in the South Asia volume of the Garland Encyclopedia of World Music (Wolf 2000, 279).
} 
rhythms began to take over the function of communicating liturgical texts as diasporic Indo-Muslims gradually began to forget the language of these texts (Korom 1994a) is not strongly supported by evidence from the subcontinent, which suggests that Muharram drumming can communicate textually even while a living tradition of liturgical recitation continues to flourish.

\section{Drum patterns and verbal texts}

How and to what extent do these rhythms "communicate lexically"? Listeners vary in their ability to recognize the resemblances between speech or poetry and drummed patterns. The link between rhythm and text may be rather arcane in cases, for example, in which drum rhythms named marsiyah are supposed to conform to the general rhythmic features (or possibly, at one time, the poetic meters) of marsiyah recitation. However, most Muslim participants recognize the linguistic basis of simple slogans rendered on the drums: "Yā "Alī" (Karachi, Jacob Lines), "Yā "Al̄̄ Yã Husain" (Hallaur; Udaipur), "Hasan Husain" (Uttaraula) "Sain Imām Husain Haidar" (Lucknow, see Wolf 2000, 280). These slogans can be easily apprehended, not only because they are prosodically elementary but also because the drumming may actually accompany participants' shouting. The inclusion one or more of the Imāms' names renders these slogans appropriate for the occasion, but sometimes the text also articulates a social aspect of Muharram: its partisan and agonistic quality. As Sharar's account in Lucknow suggested, an element of competitive display was once common in public Muharram observances and some of this spirit seems to endure today, especially in the building of ta 'ziyahs and reciting of nauhahs. In the Kārwārī Mohalla of Udaipur, Rajasthan, in addition to the familiar "Yā "Alī Yã Husain" pattern, the textual basis of one of the rhythms is "Barī Paltan," apparently a corruption of "Barī Platoon" or "Big Platoon." In colonial times the Maharaja's army would take a large and famous ta 'ziyah out on procession; by metonymic substitution the name has become indigenized and applied to a masjid (mosque). Now, on the seventh of Muharram, participants carry a large, community-owned ta'ziyah to this masjid. The $t a$ 'ziyah, once a form of glorification for the titular ruler - emphasizing the difference, as it were, between the sharif (elite) and the ordinary Muslim - has now become a symbol of a whole Muslim neighborhood, and the process of transformation is in a sense coded in the dihol-tāsā rhythm.

Slightly more complicated than these two-word slogans are meaningful phrases such as "he [the Imām] climbed onto Dul-Dul [Husain's horse] and the infidels were slain" (carhe duldul kațe käfir) (98/In1/p.74 7 Feb. 1998). According to Pappu Sain, the renowned malang (a type of Sufi mendicant) dhol player of the Shah Jamal shrine in Lahore, it was common to hear this rhythm performed for Muharram in the Panjab (Pakistan) about 30 years ago. Now drumming is utterly absent in Lahore during Muharram, but apparently this rhythm is performed today at the shrine of Lâl Shabāz Qalandar in Sindh. As Pappu Sain explained it, drummers use mnemonic bols similar to those encountered in Hindustani music; faqi rs attached this layer of meaning secondarily. Thus, although some Muharram rhythms are understood linguistically, this does not mean that they have all originated as verbal language.

In the Nizamuddin tradition maintained in Delhi and Karachi each of the four major Muharram rhythms is attached to a text. Some of the older musicians 
in Jacob Lines rendered for me in soz style the text for the rhythm called dhima (lit. "slow"), "Today, in Medina, Sughra is crying with tear-filled eyes" ( $\bar{a} j$ sughrā yū $\underline{n}$ madīne men hain rotī bhar ke nain) $(97 / 117,17)$. This "marsiyah," as they called it, was composed by a member of the Nizami family. In practice it is "recited" only on the drums, not verbally during majlises (mourning assemblies) as is ordinarily the case. They considered dhima to be a relatively difficult $t \bar{a} l$ (rhythmic pattern), performed first or last in a sequence, for a crowd of stationary listeners, and only for a brief time if at all.

Considering the tearful subject of this marsiyah and the defensive statement in the Nizami "Guidelines of Practice" (1989) that no mournful texts are recited in the procession one might conjecture: In this case could the transfer of medium from voice to drums have served to mask the mournful character of the texts from critical onlookers? Those Sufis and Shi 'ahs who understood the mixture of grief and elation implicated in commemoration of Husain's martyrdom could perhaps have ascertained from the sound of the drums the inner meaning of the marsiyah, which they might already have known from a tradition of tuneful recitation; those neither familiar with the texts nor sympathetic to the emotional means of propitiating the martyrs would have responded only to the drumming.

According to Sayyid Sarir Ahmed Nizami, the marsiyah refers to the historical event in which the "Great Imām" (Husain) went to fight the battle of Karbala, leaving his daughter Sughra in Medina. On hearing of her father's martyrdom, she lamented; the words of the marsiyah reproduce the "effect" ( $t a$ 'sur) of lamentation $(97 / 117,18)$. As Muhammad Baksh put it,

when we recite [i.e. play it] you can understand what the $d_{\text {hol }}$ and $t \overline{a s} \bar{a}$ are playing, such and such a tarz [tune, but here, rhythmic pattern conforming to the tune of a melodic recitation]. If you recite it in your heart [you will feel] that the dhol is saying the same thing ${ }^{42} \ldots$ if you remember the marsiyah played on the $d h o l$ tāsa your mind will recall that now this marsiyah is being played/said on tās $\vec{a}^{\prime}(97 / 117,36-37) .{ }^{43}$

For the rhythm called mātam these Karachi drummers also produced a single line of text, "when Fatima [Husain's mother, the daughter of the Prophet] came from paradise, saying 'oppressed Husain' " [jab fätmah firdaus se yeh kehtī $\bar{a} ' \bar{\imath}$ mazlü $m$ husainā (97/I17/p.76); thus the performance of mātam evokes for these drummers the impassioned grief of the Prophet's daughter for her son, Husain, who sacrificed himself in the name of Islam.

According to the "Guidelines of Practice" of the Nizami family, it was traditional for a large crowd to gather on the $9^{\text {th }}$ of Muharram at the Nizamuddin shrine in Delhi. First the Qur'än would be recited. Zākirs would then deliver learned speeches about the martyrdom of Husain and the family of the Prophet and conclude this by offering a fätiha (the first $s \bar{u} r a$ of the Qur 'ān, often used as a

\footnotetext{
42 "hamāre hān jis ko keh voh bāqā'idah āp samajh sakte hain kih hān yeh ḍ̣ol jo hai, tāshā jo baj rahā hai, ḍ̣ol tāsha yeh us kītarz men baj rahā hai. āp us ko dil me kahen to yeh ḍhol kehegā voh"

43 “āp dil men agar voh yād hai nah, voh āp ko to ḍ̣ol tāshā jo baj rahā hogā, nah, āp ke zahan men ā jā 'egā kih hān yeh martabah yahān par yeh keh rahen hain baj rahā hai ḍ̣hol tāshe par"
} 
benediction on the souls of the dead) by way of prayer. The shrine would then provide food for the masses. Following this the $t \bar{a} s \bar{a}$ players would drum a salāmi (salute), and during this time those who rendered special services were bestowed the honor of having turbans tied about their heads; following this the ta'ziyah was taken out (Nizami 1989, 8).

Although I have not confirmed the details of the ritual as it is performed today, I do know that the $t \bar{a} s \bar{a}$ master drummer, Mamraj, and his group (all Hindus) perform on this occasion in Delhi. He is given the honor of wearing the "first pagari" (i.e. turban) in this ritual, and if I understood him correctly, the first rhythm performed at this time, preceding and leading up to the lifting of the ta'ziyah, is called savāin, literally "ride" or "vehicle."44

Mamraj (b. 1933) studied drumming with the former "first pagari" of the Nizamuddin shrine, one Ustad Muhammad Sheikh. The drummers from the Nizamuddin tradition living in Karachi also spoke of Muhammad Sheikh and his role in leading a Shī $\mathbf{1}$ ta'ziyah. ${ }^{45}$ Before him, Mamraj's father, Kishan Lal performed at the Nizamuddin shrine for thirty-four years. In keeping with the ecumenical ethos of certain Sufi orders, the Muharram tradition at Nizamuddin has allowed for the participation of a variety of communities with a variety of sentimental attachments to the affair: Mamraj suggested that the drumming does not produce any emotional effect at all, people cry because the occasion is mournful. Most would not recognize the rhythms as inherently sad (98/De/In1). The "Guidelines of Practice" identified the drumming as a sign of happiness, yet one of the Sunni drummers in Karachi said that the rhythm mātam, for instance, produced a languid, downcast (sust) state in listeners, causing their hearts to be moved and inspiring tears (Hasham 97/115, 43). ${ }^{46}$

This multivalence may become transformed into a type of ambivalence when in the case of an individual, a choice must be made about emotional and political allegiances, and this is just what has happened under the influence of religious authorities or parties who have condemned both music and Shīi forms of piety. ${ }^{47}$ Shī'i religious leaders responded promptly and thoroughly to these

\footnotetext{
${ }^{44}$ They play two rhythms called savānin, one for Muharram and one for Rām Līlā. There are connotations both of royal processions and of spiritual journey implied by this word depending on context. The term savāin is commonly used for rhythmic patterns that accompany moving processions and/or the onset of spirit possession in the subcontinent. Note, contra Wadley (1976, 247 and passim), that "ride" as possession by the Karbala martyrs, often termed pirs in this context, does not imply possession by malevolent spirits.

${ }^{45}$ My understanding is the Sheikh was a Sunni (or a Sufi who did not consider himself Shi 'ah); the ta ziyah might have been that of Khurshid discussed earlier, but it was not clear from the interview (Hasham 97/115/p.48). Detailed treatment of the genealogy of Nizamuddin tāsa $k$ khanndāns (lineages) and their special repertoire lies beyond the scope of this article and will be treated separately in a later article.

${ }^{46}$ To give a sense of how I gathered such information: after discussing what the various rhythms were, and when they were played, we moved to a discussion of meaning. This comment was a response to a direct query from my assistant, "what is the state/condition (kaifiyat) of people [when mātam is played on the drums]?"

${ }^{47}$ For example, note three representative criticisms levelled against $\mathrm{Shi}{ }^{-}$'ahs by the prominent theologian, Shāh 'Abd Al-'Az̄̄z. Aziz led a circle of influential reformist thinking in Delhi from 1763 to 1824 and published an extensive, if somewhat vicious and ill-informed diatribe against Shī 'ism that was completed in about 1790 . Similar criticisms persist today.
}

- As children are excited with their toys and dolls and perform various dramas, so 
vicious attacks; but notably, they did not defend local "superstitious" practices, ascribing them, rather, to ignorant village people who were not fully conversant with true Islam. But despite a history of communal clashes during Muharram in south Asia that can be traced at least to the $17^{\text {th }}$ century, tolerance and ecumenism remain even in such an unlikely urban area as the city of Delhi. The public procession from Nizamuddin is an interesting example because, from what the Hindu drummers told me, it does not serve so much as a cultural performance of a sectarian identity, as Muharram processions so often do, but rather of an interfaith Sufi identity in which Hindus also participate. "I don't believe in any demarcation of religion," to paraphrase Mamraj. Based on our discussions, it would appear that he and his troupe experience no spiritual dissonance in performing one of the ritually less important Muharram rhythms, called kalma, named after the Islamic declaration of faith: "there is one god, Allah, and Muhammad is his prophet."

The question of exactly how drum rhythms reflect their texts will be the subject of a future article; as a preliminary observation, the rhythms appear to be stylized interpretations of subjective experiences of the texts, rather than systematic applications of poetic metrical rules to the drums; neither do the rhythms simply articulate long and short syllables. For the purposes of this article it will suffice to examine the tâl called kalma. Presented in the appendix (Ex. 1) is the ostinato which defines the rhythm; against this, tāsa players will take turns improvising in the manner of a jazz musician against a set of chord changes. This ostinato is the "tune," and in fact the Delhi musicians whom I interviewed used the Persian term, naghma, to refer to the $d h o l$ beat, which essentially defines the piece. There is an intermediary layer of ostinato performed on the $t \bar{a} s \bar{a}$ which also appears in the notation. Not all d structure, but it is noteworthy that this structure can be found in contemporary Trinidadian groups. ${ }^{48}$

the Shĩ 'ahs create dramas around the replicas of the graves of Ali, Hassan, Husain and Fatima. They believe they are real graves and that those eminent personalities are really there. They exhibit great respect and even prostrate themselves before them. These stupid acts reduce adult imagination to childish fantasy (Rizvi 1982, 337-38).

- The Shĩ $\mathbf{1}$ popular beliefs are very well known, but their religious leaders do not commit them to writing. One such belief is that by weeping, making images and playing instruments as acts of worship on the tenth of Muharram, their sins would be remitted (Rizvi 1982, 340-41).

- While the Hindus worship idols, the Shi 'ahs worship the effigies of their imam's graves (ta 'ziyahs). The Hindus bathe their images, place them in carriages, play musical instruments to them, and place food before them, distributing it also to others. The Shī 'ahs celebrate Imam Qasim's wedding exactly like that of a living being. They are more superstitious than the Hindus (Rizvi 1982,351 )

Shī $\uparrow$ religious leaders responded promptly and thoroughly to these vicious attacks; but notably, they did not defend local "superstitious" practices, ascribing them, rather, to ignorant village people who were not fully conversant with true Islam.

${ }^{48}$ In Trinidad musicians called the dhol the "bass," the $t a \bar{s} a \bar{a}$ ostinato part the "fuller," and the tâsā improvisational part the "cutter." According to Frank Korom, Trinidadians whom he interviewed felt that the jhannjh made the rhythms sound sadder (May 2000, pers. com.). A number of ethnographic details provided informally by Korom in this article will appear in his book, cur- 


\section{Aesthetics of the Expressive Potential of Drumming and "Music"}

Relationships between drum rhythms and speech in south Asia are abstract, indeed more abstract than those between the tonal rhythms and languages of subSaharan Africa. But in both cases, drummed language is ambiguous, interpretable only through context. When we approach aesthetics we are not dealing simply with criteria of "beauty" but more broadly with how a creative form is appreciated, how people make sense of it. We may say that one of the ways that people recognize the value of drumming, across south Asian regions and communities, is by attributing relevant textual messages to drum rhythms. However, lexical aspects of drumming do not generally communicate the fine-grained feelings associated with an occasion, nor is the message altered by the way in which something is performed. To broach matters of feeling we must move beyond the gross "message," so to speak, and address the style in which it is proclaimed.

\section{Timbre and tessitura}

Timbre and tessitura of indefinite pitch tend to vary together on the drums. Higher tessitura tends to be articulated with a sharp, crisp stroke; deeper drum sounds tend to be more muffled. This corresponds with the tendency to play drums of higher pitch such as the tāsa with thinner sticks than drums such as the dhol or naqärah, which can be played either with heavier sticks, or with the hands, depending on factors of local style or context.

My attention was drawn to the importance of timbre and pitch during an interview with Muhammad Baksh, a naqärah kettledrum player and radio artist in Multan, Panjab, Pakistan. ${ }^{49}$ Baksh, a Sunni, expressed a moral disdain for the use of the dhol-tāsā during Muharram even though he himself used to play a different kind of $d h o l$ until his $p \bar{\imath} r$ (spiritual preceptor) forbade it -apparently because he felt that any form of music was inappropriate for Muharram. Multani musicians, who are sometimes but not always Mīrāsīs, continue play the dhol and sahnāì during Muharram - but never the $t \bar{a} s \bar{a} .^{50}$

That is not to say that Baksh had no connection with the tāsā whatsoever. In pre-partition days he used to perform the $t \bar{a} s \bar{a}$ for Hindu weddings and he was even able to dredge up an allegedly eighty-year-old instrument on which to demonstrate. But it was clear that, in Baksh's mind, the $t \bar{a} s \bar{a}$ was indexical of both a community and a context cognitively opposed to Muharram. Tāsā was at one time played during Muharram in Multan, but not by native Multanis, rather by

rently in preparation, provisionally entitled, Hosay Trinidad: Muharram performances in a Caribbean context. Jhānjh was not a part of all dhol-tāsā ensembles I encountered; its absence in some cases was not the result of an aesthetic choice, but rather of the fact that the instrument is relatively expensive and potentially the object of theft. The " $s$ " sound of phrases such as "HasanHusain" seems most clearly to be articulated on these cymbals when they are freely resonating or slightly touching one another. I have gathered no specific information about their emotive capability.

49 Photographs of Baksh appear in the South Asia volume of the Garland Encyclopedia of World Music (Wolf 2000, 283 [bottom]; Nayyar 2000, 764 [far right]).

50 Mīrīsīs are hereditary musicians who operate in both folk and classical worlds. Neuman provides brief background information on this class of musicians and their social position in the musical culture of Delhi (Neuman 1980, 124-35). 
muhäjirs, who until the 1960s used these drums to accompany a martial display with swords. The muhäjir tradition died out for complex reasons, perhaps due to local prejudice against imported traditions, or objections to the manner in which the swords were brandished. Although, despite his pīr's admonition, Baksh did not condemn the practice of performing the $\mathbf{d h o l}$, he felt that the performance of tāsā during Muharram was somehow immoral. Why, I asked him, was dhol playing marginally acceptable during Muharram but not $t \bar{a} s \bar{a}$ ? Baksh did not merely argue that the $t \bar{a} s \bar{a}$ was inappropriate because of the association with Hindu weddings, he spoke of musical features: He felt that the deep pitch and timbre of the $d h o l$ both better suited the sadness of the occasion and carried further, thus serving better to announce the beginning of Muharram or the procession. The high pitch and strident timbre of $t \bar{a} s \bar{a}$ drum strokes did not seem sufficiently lachrymose to him. Nor, in his opinion, could the instrument project its sound as far as could the $\mathbf{d h o l}$. The association Baksh drew between timbre, pitch and emotion did not surprise me because intuitively the same loose association holds in my own culture.

Jean-Jacques Nattiez $(1990,122)$, for example, pointed out that for a Western musician, certain tonal symbols seem natural. He provided the following chart:

$\begin{array}{lllll}\text { high } & \text { shrill } & \text { clear } & \text { joyous } & \text { (and so forth) } \\ \text { low } & \text { deep } & \text { dark } & \text { sad } & \text { (and so forth) }\end{array}$

I would perhaps add "brisk tempo" to the musical correlates of "joyous" and "slow tempo" to that of "sad." Western listeners might offer these kinds of abstractions in the absence of a particular musical application; as abstractions, they conform reasonably well to the kinds of statements that (a necessarily small number of) Indians and Pakistanis with whom I spoke think about happiness and sadness musically. Baksh's explanation bore out either implicitly or explicitly when I interviewed several other musicians and listeners in areas where traditions of $t \bar{a} s \bar{a}$ coexisted with drumming traditions consisting primarily of deeper pitched instruments such as ${ }_{\text {h }}$ ol or naqārah; a number of interviewees could not explain why $t \bar{a} s \bar{a}$ sounded joyous or exciting and not sad to them; a minority felt that pitch and timbre of drumming had nothing to do with the emotional content.

Although one must resist the temptation to allow interpretively colorful colonial period descriptions to stand alongside primary field materials without critical comment, it is worthwhile in this context to excerpt from Mrs. Meer Hassan Ali's description of a Muharram procession, presumably from Lucknow sometime between 1816 and 1828 (Ali 1974, xi):

The whole line of march is guarded in each procession by burkhandhars (matchlock men), who fire singly, at intervals, on the way. Several bands of music are dispersed in the cavalcade, performing solemn dirge-like airs, peculiar to the style of composition in Hindoostaun, and well suited to the occasion, - muffled drums and shrill trumpets, imitating the reiteration of 'Hasan, Hosein,' when Mortem [i.e. $m \bar{a}$ tam] is performed. I remember a fine female elephant, belonging to King Ghauzee ood deen Hyder, which had been so well instructed, as to keep 
time with the soundings from her proboscis with the occasional Mortems . . . (Ali 1832, 87-8, italics mine)

The details of this rich account bear attention. The comic image of the elephant's trunk suggests that all elements in the procession were in moral and rhythmic sync with one another, possibly indexing the temporary solidarity among communities participating in Muharram together. Mrs. Ali's twelve years' experience of Muharram as a mournful context probably influenced her interpretation of the band music as "dirge-like" (it did not strike me as dirge-like in 1998). She notes contrasting timbres, "muffled drums and shrill trumpets." The muffled effect of the drums - probably not $t \bar{a} s \bar{a} s$, but naqārahs ${ }^{5 l}$ - may have been a result of the instruments being performed with the hands, as they sometimes are

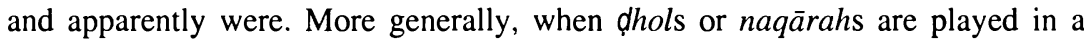
procession, their upper partials (which are not anyway emphasized, for the sticks tend to be hefty) dissipate over the distance, losing their reverberation in the mass of bodies. But what about shrillness? Is shrillness an appropriate timbre for Muharram or appropriate merely for the trumpet? Is shrillness iconic of human cries of woe, as Mrs. Ali's description might imply? If so, that might explain why shrill, bright timbres, unlike their percussive analogues, are not criticized when they are issued upon aerophones.

But there are other contextual considerations as well. It is noteworthy, for instance, that hereditary musicians both in Hyderabad, Sindh (manganhars) and in Hyderabad, Andhra Pradesh, use a type of double reed aerophone, śahnāit, when they perform during Muharram that is shorter than the one they use for a concert or a wedding. In Andhra Pradesh, the musicians with whom I spoke belong to one of the khandāns (musical families) that has been, since the days of the Nizāms, traditionally charged with the responsibility of keeping the hours in the "drum house" (naqār khānah) - in this instance, at the Sufi shrine of Yusufain. As they understand it, the function of such a sahnāi is to project the sound over long distances, much as Baksh understood the function of the Muharram. In this mode of explanation, it makes sense that the shriller instrument is used in the naqär khänah both for Muharram and for announcement of the hours. At a wedding or in concert, where the setting is more intimate and the repertoire less limited by ritual restrictions, the larger instrument becomes more

\footnotetext{
${ }^{51}$ The size and shape of the instrument described in her account could apply equally well to the naqārah and the $t \bar{a} s \bar{a}$, however the reference to a pair of drums would suggest the former. The thin hoop is not characteristic of either instrument, to my knowledge, when the body is fashioned of clay. "Amongst the many varieties of Native musical instruments I have seen in India, the kettle-drum is the most simple and singular, which I will take the liberty of describing: It is of well-baked earth, moulded in the usual way, and very similar in shape to those of the Royal Horse Guards. A globe of the common size, divided into exact halves, would be about the dimension and shape of a pair of Indian manufacture; the parchment is strained over the open mouth, with a thin hoop to fix it firm; the slightest pressure with the fingers on this hoop draws it into tune. The simplicity of this accompaniment to the human voice, when touched by the fingers, very much in the way Europeans use the tambourine is only to be appreciated by those who have been long acquainted with the sound. The only time it is beaten with sticks is, when used as dunkahs [kettle drums often tied to camel- or horse-back], before King and Queen, on their appearing in public - a sort of alarm to warn obstructing hackeries, or carriages, to move out of the way." (Ali 1832, 88-90).
} 
suitable for expressive purposes. It is phenomenologically true that in both locations, Andhra Pradesh and Sindh, the distinction between Muharram and weddings is maintained assiduously through the use of different versions of the same musical instrument. ${ }^{52}$ That is, difference is embodied both timbrally and materially. But one cannot understand the choice of instrument in terms of the broad aesthetic categories that appear almost natural - even to some south Asians those that associate bright timbres with celebration and dark timbres with mourning.

\section{Tempo and cadence}

In discussing the sound of the drums with a variety of consultants, sometimes literally "men on the street" during a festival, sometimes musicians, it was often difficult to isolate technically particular aspects of the sound. The $t \bar{a} s \bar{a}$ ' $s$ pitch, sharpness, and brightness of timbre, for example, could not be considered in the abstract without also remembering its rapid tempo. On the tãsā, all rhythms are improvised upon with rapid strokes, the rapidity, in part, communicating the sense of excitement, or josh, associated with processions and thoughts of the battle of Karbala.

I attempted, therefore, to inquire about aspects of tempo and rhythmic cadence as perceived in other forms of Muharram sonic art. I approached Karrar Qazmi (the consultant who had told me that Hyderabadis considered soz to be excessively musical), after Amy Bard finished a recording and interview session with him concerning her doctoral topic, the Urdu marsiyah. I explained that I had come across drum rhythms composed to articulate the contours of Shi's poetry and wondered whether he knew of other examples of this phenomenon, or had any personal ideas as to its significance. After a moment's consideration he recalled not merely a drum rhythm, but a melody performed by wedding band instruments and drums. ${ }^{53}$ Qazmi sang the accompanying text to a lively, almost playful, melody which seemed to belie the seriousness of the subject (See Ex. 2 in the appendix).

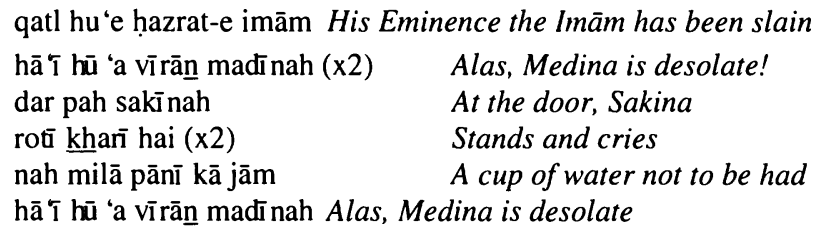

I asked Mr. Qazmi what he considered to be the emotional import of this piece. Not surprisingly, given the textual and contextual association with Muharram, he felt that the piece was a sad one. But many who hear this piece in a public gathering will gain an impression of the music which is divorced from its textual referent, merely drawing inferences from the sound of the band instru-

\footnotetext{
${ }^{52}$ One of Frank Korom's consultants went so far as to assert that the tāsā could only truly be called a $t \bar{a} s \bar{a}$, and its rhythms (called "hands") $t \bar{a} s \bar{a}$ hands, when the instrument is played for Hosay, even though it is also used for occasions such as weddings and competitions (Korom May 2000, pers. com.).

${ }^{53}$ Gregory Booth (e.g. 1990) has discussed extensively the history, instrumentation and social context of these bands in India.
} 
ments alone, the melody, and its rhythmic character. Furthermore, the context for such a performance is the so-called mehndi (henna) ritual. In a common south Asian redaction of the Karbala story, Husain did not want his son Qasim to die in battle, never to have married. So, a wedding was staged before the battle commenced. In elaborate Muharram observances, the wedding of Qasim is "celebrated" on the seventh of the month of Muharram with wedding songs and band music. This is an example of ironic or poignant happiness, encompassed as it is in a mournful frame. Participating in such a celebration are generally those who accept an emotionally textured understanding of Muharram; but some continue to emphasize sorrow and find the wedding band distasteful.

Returning to a musical discussion, I asked Mr. Qazmi to speculate. ${ }^{54}$ What if he had heard the wedding band playing the piece and did not know the text? Considered in this light, he felt indeed that the music would not have struck him as particularly mournful. This points out a characteristic, and yet ironic, sort of heterogeneous relationship among elements of Muharram performances. Part of Qazmi's evaluation was based on tempo, and indeed a number of my consultants seemed to feel that for music to sound sad it must be languid. I do not wish to digress for an elaborate discussion of methodology at this juncture, but simply wish to reemphasize that aesthetic abstractions almost vanish once music is contextualized.

\section{Conclusion: Contemplating Music}

I shall conclude by moving outside the world of musicians in the direction of the wider population, suggesting a few of the ways in which Muharram drumming registers in continuing chains of signification, while relating back to a few core ideas. Some individuals use drumming in Muharram as a point of departure for contemplating the events at Karbala. I approached Prof. Atahar Raza Bilgrami of the Economics department, Jamia Millia University in Delhi, a Shī 'ah currently preparing a book on Muharram observances in Urdu. He understands the three styles of $\underline{d h o l-t a \bar{s}} \bar{a}$ performance in his hometown of Bilgram as commemorating three phases of the battle of Karbala. The first, regular tempo suggests to him the marching of troupes, "left-right-left-right"; a subsequent style of accelerated, loud, and feverish drumming evokes the attack. Finally, a regular, slow, calm and quiet style of drumming reflects, "the last moment when the whole thing is decided, the flattened bodies." 55

I found the specificity of Bilgrami's interpretations curious, for drummers themselves never offered such precise meanings. In fact they would not be able to offer such interpretations, according to Prof. Bilgrami, because not only did they lack the educational background that would foster such imaginative attributions but also their Sunni religious background would not be conducive to such

\footnotetext{
${ }^{54}$ See Gell for the methodological problems of counterfactuals and the presumption of multiple worlds (Gell 1996). These problems aside, I believe it belittles our consultants' intelligence to assume $a$ priori that they cannot abstract, or distance themselves from concrete events, in the ways we expect intelligent individuals to be capable of doing in our own cultures.

${ }^{55}$ Frank Korom (May 2000, pers. com.) pointed out the remarkable similarity between this formulation and the sequence of Hosay drum rhythms in Trinidad: 1) "marching hand," 2) "war hand," 3) "dead hand" or "drum of sorrow."
} 
contemplation. In saying this, he implied, interestingly, that drummers, through their artistic ability, are able to perform cultural and religious roles that they do not themselves fully understand. In contrast to the widely-held, if simpler, view associating a drum as a kind of an object with a particular context, Bilgrami's outlook did not find the popularity of $t \bar{a} s \bar{a}$ drumming at weddings to be problematic. "The rhythms are different," he told me; Muharram drumming is characterized by comparatively longer gaps between scription thus supported another common idea, namely that a deeply pitched instrument played in slow tempo contributes to an aesthetic of mourning.

This article has detailed a variety of ways in which individuals' interpretations of a particular context for drumming have bled into the ways in which they interpret its content. This bleeding is apparent in linkages between drums as physical objects and the occasions and identities of particular communities; it is also manifest in the ways rhythms are attributed lexical meanings; and it is exemplified in the ways in which expressive parameters of performance such as timbre and tempo are understood. Although most south Asian Shī 'ahs today would summarize the emotional impact of Muharram as one of sadness, gham, there is in fact a palette of sentiment and feeling involved in the performance of narratives and rituals. Musical culture exemplifies the emotional multivalence, if not ambivalence, diverse Muharram participants articulate through their ritual practices.

Muharram is an example, but not the only example, of a so-called "mournful" event which is characterized by a host of complex emotions, including those that are celebratory. The pageantry of Muharram has articulated for participants something of an optimism, pride, and artistic aesthetic, one that shows respect for the Imāms, who are spiritually present, and actually provides a form of entertainment for them. Some find the military association of $t \bar{a} s \bar{a}$ drumming appropriate for commemorating the sense of josh, or excitement in the battle of Karbala; but some Shī 'ahs bristle at this association, citing famous marsiyahs by Anis, Dabir and others, in which the enemies of Husain beat the drums each time they slaughtered a member of the Prophet's family. Complex emotional attitudes to Muharram arise from complex types of participation and interpretation, and this results in an enduring ambivalence about the art (or non-musical ritual duty, depending on the tradition) of drumming.

It is perhaps appropriate to conclude with a return to the theme of ambiguity, examining not drumming, its textual glosses or contemporary meanings, but a tradition of oral recitation containing references to drumming and on which individuals may further base their understandings about this phenomenon. One of the poets of the classical Urdu marsiyah, Mirza Dabir, composed the following stanzas, excerpted from a performance at a women's majlis in Lahore, recorded and translated by Amy Bard.

Halting his mount, he questioned his companions,

It was at the onset of Muharram month that our Master arrived

"Well, my exiled ones, we've come upon this wild desert;

Shall we pitch the tents all here?" They said "Well and good."

"But how many days, King of Faith, is it your intention to stay?"

Replied the King, "This spot will be our place until doomsday!" 
All of a sudden, enemies approach the tents!

All over, the sounds of tambourine, kettledrums and horns rang out!

Zainab cried out, "Oh exalted Sayyid,

Is that perhaps the band come to welcome you over there?

These folk must have come to fetch us strangers!

It must be a message of hospitality they're sending you."

"It's death that will come to fetch us," said the King ...

Zainab, Husain's sister, hears the sound of tambourine, kettle drums and horns, and thinks the local people of Karbala are coming to greet them after their arduous journey from Medina; but alas, it is the enemy, sending a message not of hospitality, but of death.

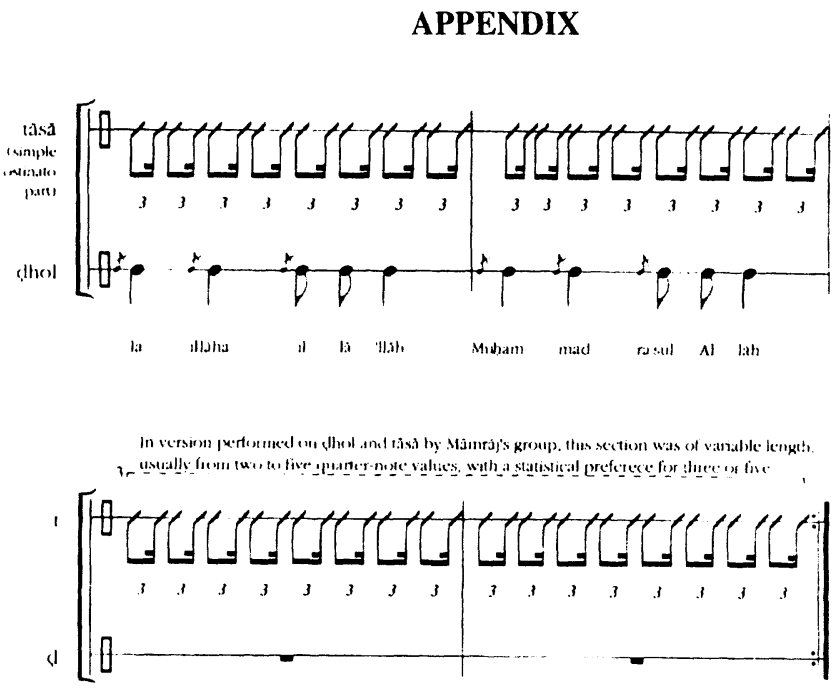

Example 1. Kalmah. Text dictated in rough form by Māmrāj. Third part is improvised on $t \bar{a} s \bar{a}$ (not notated here). 

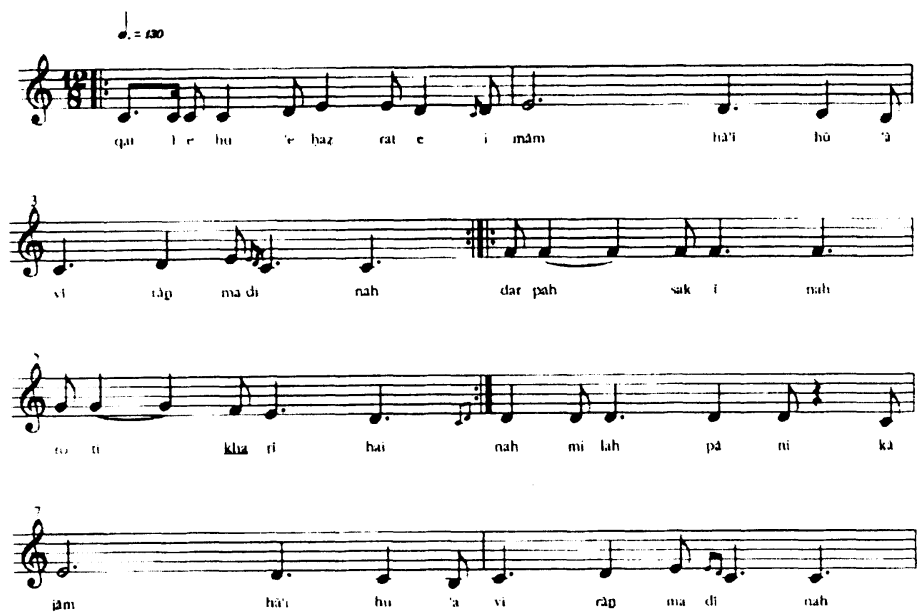

Example 2. Qatl hu'e hazrat-e imām. As demonstrated by Karrar Qazmi, Hyderabad, 30 May 1998. This piece is sometimes played by brass band for the "mehndi" of Qasim on 7 Muharram.

\section{RECORDINGS}

Field recordings cited here are available for consultation at the Archives and Research Center for Ethnomusicology in Gurgaon, outside of New Delhi. The numbering system is as follows:

The first number usually refers to the year, $98=1998$

The second set of letters (if there are three sets of characters separated by slashes) is an abbreviation for the region or town in which the particular recording was initially made. Sometimes there are multiple regions represented in a single recording

The third set of letters and numbers (or second if there are only two sets of characters separated by a slash) refers to the type or medium of recording and the sequential number within the series. In = interview (usually on analogue cassette tape); $\mathrm{V}=$ video (usually $8 \mathrm{~mm}$ ); $\mathrm{D}=\mathrm{DAT}$ tape; $\mathrm{A}=$ Analogue cassette tape, usually musical performance.

Page numbers refer to verbatim transcripts of some of these tapes. 


\section{REFERENCES CITED}

Al-Faruqi, Lois

1985 The sound arts of music. In Islam and art, 175-209. Islamabad: National Hijra Council.

Ali, Mrs. Meer Hassan

1832 Observations on the Mussulmauns of India: Descriptive of their manners, customs, habits and religious opinions made during a twelve years' residence in their immediate society. 2 vols. London: Parbury, Allen, and Co.

1974 Observations on the Mussulmauns of India: Descriptive of their manners, customs, habits and religious opinions made during a twelve years' residence in their immediate society. $2^{\text {nd }}$ ed., ed. with notes and an introduction by W. Crooke. Reprint of 1917 edition. London: Humphrey Milford, Oxford Univ. Press.

Ali, Shair

1990 Hosay: Symbols of martyrdom. Trinidad Guardian (17 July): 4. Cited in Korom 1994b.

Arnold, Alison, ed.

2000 South Asia: The subcontinent. The Garland Encyclopedia of World Music volume 5. New York: Garland Publishing, Inc.

$\rightarrow$ Booth, Gregory

1990 Brass bands: Tradition, change, and the mass media in Indian wedding music. Ethnomusicology 34(2): 245-70.

$\rightarrow$ Cannon, Aubrey

1989 The historical dimension in mortuary expressions of status and sentiment. Current Anthropology 30(4): 437-58.

$\rightarrow$ Capwell, Charles

1995 Contemporary manifestations of Yemeni-derived song and dance in Indonesia. Yearbook for Traditional Music 27:76-87.

Census of India

1961 Muharram in two cities (Lucknow and Delhi). Monograph series, vol. 1. New Delhi: Office of the Registrar General India, Ministry of Home Affairs.

1971 A monograph on Muharram in Hyderabad city. Series 2: Andhra Pradesh. Field investigation and draft, Khaja Moinuddin, Scrutiny, V. Venugopal Rao, ed, T. Vedantam. New Delhi: Office of the Registrar General India, Ministry of Home Affairs.

Cole, J. R. I.

1989. Roots of north Indian Shïism in Iran and Iraq: Religion and state in Awadh, 1722-1859. Delhi: Oxford University Press.

Farmer, Henry George

1939 The instruments of music on the Tāa-i Bustān bas reliefs. In Studies in oriental musical instruments, 70-85. Glasgow, The Civic Press, 1939. 
Feener, Michael

1999 Tabut: Muharram observances in the History of Bengkulu. Studia Islamica 6(2): 87-130.

1995 Upacara Tabot: Muharram tradition and the imagination of Bengkulu. M.A. Thesis, Boston University.

$\rightarrow$ Flora, Reis

1995 Styles of the śahnāi in recent decades: From naubat to gāyaki ang. Yearbook for Traditional Music. 27: 52-75.

Gell, Alfred

1996 The anthropology of time: Cultural constructions of temporal maps and images. Reprint (originally published, 1992). Oxford: Berg.

Good, Mary-Jo Delvecchio and Byron Good.

1988. Ritual, the state, and the transformation of emotional discourse in Iranian society. Culture, Medicine and Psychiatry 12(1): 43-63.

Grabes, Herbert

1997 Aesthetic emotion. In Emotion in postmodernism, ed. Gerhard Hoffman and Alfred Hornung, 321-45. Heidelberg: Universität C. Winter.

Grima, Benedicte

1993 The performance of emotion among Paxtun women. Karachi: Oxford University Press.

Hasan, Mushirul

1990 Sectarianism in Indian Islam: The Shia-Sunni divide in the United Provinces. The Indian Economic and Social History Review 27(2): 20928.

1997 Traditional rites and contested meanings: Sectarian strife in colonial Lucknow. In Lucknow: Memories of a city, 114-35, ed. V. Graff. Delhi: Oxford Univ. Press.

Hasnain, Nadeem and Sheikh Abrar Husain

1988 Shias and Shia Islam in India: A study in society and culture. New Delhi: Harnam Publications.

Islam, Riazul, ed.

1980 Maḥmū d b. Amīr Wal̄ Balkhī, The Baḥr ul-Asrār travelogue of south Asia. Introduction and annotation by Riazul Islam. Karachi: Institute of Central and West Asian Studies, University of Karachi.

Kartomi, Margaret

1986 Tabut A Shī 'a ritual transplanted from India to Sumatra. Nineteenth and twentieth century Indonesia: Essays in honor of Professor J. D. Legge, 141-62, ed. Chandler, David P. and M. C. Ricklefs. Clayton, Victoria, Australia: Centre of Southeast Studies Monash University.

Korom, Frank

1994a The transformation of language to rhythm: The Hosay drum of Trinidad. World of Music. 36(3): 68-85.

1994b Memory, innovation, and emergent ethnicity: The creolization of an Indo-Trinidadian performance. Diaspora 3(2): 135-55.

Kumar, Nita

1988 The artisans of Banaras: Popular culture and identity, 1880-1986. Princeton: Princeton University Press. 


\section{4/ 2000 YEARBOOK FOR TRADITIONAL MUSIC}

Kupperman, Joel J.

1997 The disunity of emotion. In Emotion in postmodernism, ed. Gerhard Hoffman and Alfred Hornung, 363-381. Heidelberg: Universität C. Winter.

\section{Laxmaiah M}

1998 Cappannu jātula 'dū lāt’ p̄̄rlapanḍaga [Telugu]. Janapāni, (May):18-19

$\rightarrow$ Leavitt, John

1996 Meaning and feeling in the anthropology of emotions. American Ethnologist 23(3): 514-39.

$\rightarrow$ Lyon, Margot

1995 Missing emotion: The limitations of cultural constructionism in the study of emotion. Cultural Anthropology 10(2): 244-63.

Lutz, Catherine

1988 Unnatural emotions. Chicago: Univ. of Chicago Press.

$\rightarrow$ Malarney, Shaun Kingsley

1996 The limits of "state functionalism" and the reconstruction of funerary ritual in contemporary northern Vietnam. American Ethnologist 23(3): 540-60.

Masselos, Jim

1982 Change and custom in the format of the Bombay Mohurrum during the nineteenth and twentieth centuries. South Asia: Journal of South Asian Studies (Nedlands, Australia) 5(2): 47_67

Metcalf, Peter and Richard Huntington

1991 Celebrations of death: The anthropology of mortuary ritual. $2^{\text {nd }} \mathrm{ed}$. Cambridge: Cambridge Univ. Press.

$\rightarrow$ Mines, Mattison

1975 Islamisation and Muslim ethnicity in south India. Man n.s. 10(3): 40419.

Moezzi, Mohammed Ali Amir

1994 The divine guide in early Shi 'ism: The sources of esotericism in Islam. Tr., David Streight. Albany: State University of New York Press.

Moffatt, Michael

1979 An untouchable community in south India: Structure and consensus. Princeton: Princeton University Press.

$\rightarrow$ Myers, Fred

1988 The logic and meaning of anger among Pintupi Aborigines. Man n.s. 23(4): 589-610.

Nasr, Seyyed Hossein

1997 Islam and music: The legal and spiritual dimensions. In Enchanting powers: Music in the world's religions, 220-35, ed. Lawrence Sullivan. Cambridge, Massachusetts: Harvard University Center for the Study of World Religions.

Nattiez, Jean-Jacques

1990 Music and discourse: Toward a semiology of music, tr. Carolyn Abbate. Princeton: Princeton Univ. Press.

Nayyar, Adam

2000 Punjab. In South Asia: The Indian subcontinent, 762-72. The Garland Encyclopedia of World Music, vol. 5. New York: Garland. 
Nelson, Kristina

1985 The art of reciting the Qur' an. Austin: Univ. of Texas Press.

Neuman, Daniel

1980 The life of music in north India: The organization of an artistic tradition. Chicago: University of Chicago Press.

Nizāmī, Sayyid 'Ā̄̄ 'Abbās

1989 khāndān-e-nizāmī kā'aqìdah vah distū r ul'amal: 'urās buzurgān-e-dīn vah dīgar [Guidelines of Practice and Faith of the Nizāmī family for the urses of the great religious people and others]. [Karachi]: Special publication of the Nizāmī Institute.

Ortner, Sherry

1979 On key symbols. In Reader in comparative religion: An anthropological approach, $4^{\text {th }}$ ed, 92-98, ed. Lessa, W. and E. Vogt. New York: Harper and Row.

Parks, Fanny

1850 Wanderings of a pilgrim in search of the picturesque, during four-andtwenty years in the East with revelations of life in the zenāna. London: Pelham Richardson.

Pinault, David

1992 The Shiites: Ritual and popular piety in a Muslim community. New York: St. Martin's Press.

$\rightarrow 1999$ Shia lamentation rituals and reinterpretations of the doctrine of intercession: Two cases from modern India. History of Religions 38(3): 285305.

$\rightarrow$ Qureshi, Regula

1981 Islamic music in an Indian environment: The Shiah majlis. Ethnomusicology 25: 41-67.

Raheja, Gloria G. and Ann G. Gold

1994 Listen to the heron's words: Reimagining gender and kinship in North India. Berkeley: Univ. of California Press.

Rahman, Fazlur

1979 Islam $2^{\text {nd }}$ ed. Chicago: University of Chicago Press.

Rizvi, Saiyid Athar Abbas

1980 Shāh Walī-Allāh and his times: A study of eighteenth century Islām, politics and society in India. Canberra: Må rifat Publishing House.

1982 Shāh 'Abd Al-' Az̄z: Puritanism, Sectarian Polemics and Jihād. Canberra: Må rifat Publishing House.

Roy Choudhury, M. L

1957 "Music in Islam." Journal of the Asiatic Society. Letters. 23(2): 43-102.

Sakata, Hiromi Lorraine

1983 Music in the Mind: The Concepts of Music and Musician in Afghanistan. Kent, Ohio: The Kent State University Press.

Schutz, Alfred

1964 "Making Music Together: A Study in Social Relationship." In Collected Papers II: Studies in Social Theory. Ed. A. Broderson. The Hague: Martinus Nijhoff. 


\section{6/2000 YEARBOOK FOR TRADITIONAL MUSIC}

\section{Sharar, Abdul Halim}

1994 Lucknow: The Last Phase of an Oriental Culture. Trans. and eds. E. S. Harcourt and Fakhir Hussain. (Trans. of guzishtah lakhnau) Repr. Delhi: Oxford University Press.

1965 gužishtah lakhnau yā mashraq̄i tamaddun kā ākhharī namunah (tārī $\underline{k h} \bar{\imath}$ va jaghräfìyä $\bar{\imath}$ halāt). Reprint. Lucknow: Nasim Book Depot.

Strathern, Andrew

1993 Organs and Emotions: The Question of Metaphor. Canberra Anthro-

Tingey, Carol pology 16(2): 1-16

1994 Auspicious Music in a Changing Society: The Damāi Musicians of Nepal. London: School of Oriental and African Studies, University of London.

$\rightarrow$ Turino, Thomas

1999 "Signs of Imagination, Identity, and Experience: A Peircian Semiotic Theory for Music." Ethnomusicology 43(2): 221-55.

Venbrux, Éric

1993 "Les politiques de l'émotion dans le rituel funéraire des Tiwi d'Australie." L'Ethnographie 89(1): 61-77.

Wadley, Susan

1976 'The Spirit 'Rides' or the Spirit 'Comes': Possession in a North Indian Village." In The Realm of the Extra-human: Agents and Audiences, 233-51. Ed. Agehananda Bharati. The Hague: Mouton Publishers.

Wolf, Richard K.

2000 "Music in Seasonal and Life-cycle Rituals." In South Asia: The Indian Subcontinent, 272-87. The Garland Encyclopedia of World Music, 5. New York: Garland Publishing Co.

[Forthcoming] "Emotional Dimensions of Ritual Music Among the Kotas, a South Indian Tribe." Ethnomusicology. 